\title{
Anthropogenic aerosol radiative forcing in Asia derived from regional models with atmospheric and aerosol data assimilation
}

\author{
C. E. Chung ${ }^{1}$, V. Ramanathan ${ }^{2}$, G. Carmichael ${ }^{3}$, S. Kulkarni ${ }^{3}$, Y. Tang ${ }^{3}$, B. Adhikary ${ }^{3}{ }^{*}$, L. R. Leung ${ }^{4}$, and Y. Qian ${ }^{4}$ \\ ${ }^{1}$ Gwangju Institute of Science and Technology, South Korea \\ ${ }^{2}$ Scripps Institution of Oceanography, La Jolla, California, USA \\ ${ }^{3}$ University of Iowa, Iowa City, USA \\ ${ }^{4}$ Pacific Northwest National Laboratory, Washington, USA \\ *now at: School of Engineering, Kathmandu University, Dhulikel, Nepal
}

Received: 17 November 2009 - Published in Atmos. Chem. Phys. Discuss.: 15 January 2010

Revised: 10 June 2010 - Accepted: 18 June 2010 - Published: 5 July 2010

\begin{abstract}
An estimate of monthly 3-D aerosol solar heating rates and surface solar fluxes in Asia from 2001 to 2004 is described here. This product stems from an Asian aerosol assimilation project, in which a) the PNNL regional model bounded by the NCEP reanalyses was used to provide meteorology, b) MODIS and AERONET data were integrated for aerosol observations, c) the Iowa aerosol/chemistry model STEM-2K1 used the PNNL meteorology and assimilated aerosol observations, and d) 3-D (X-Y-Z) aerosol simulations from the STEM-2K1 were used in the Scripps Monte-Carlo Aerosol Cloud Radiation (MACR) model to produce total and anthropogenic aerosol direct solar forcing for average cloudy skies. The MACR model and STEM-2K1 both used the PNNL model resolution of $0.45^{\circ} \times 0.4^{\circ}$ in the horizontal and of 23 layers in the troposphere.

The 2001-2004 averaged anthropogenic all-sky aerosol forcing is $-1.3 \mathrm{Wm}^{-2}$ (TOA), $+7.3 \mathrm{Wm}^{-2}$ (atmosphere) and $-8.6 \mathrm{Wm}^{-2}$ (surface) averaged in Asia $\left(60-138^{\circ} \mathrm{E}\right.$ and Equator- $45^{\circ} \mathrm{N}$ ). In the absence of AERONET SSA assimilation, absorbing aerosol concentration (especially $\mathrm{BC}$ aerosol) is much smaller, giving $-2.3 \mathrm{Wm}^{-2}$ (TOA), $+4.5 \mathrm{Wm}^{-2}$ (atmosphere) and $-6.8 \mathrm{Wm}^{-2}$ (surface), averaged in Asia. In the vertical, monthly forcing is mainly concentrated below $600 \mathrm{hPa}$ with maximum around $800 \mathrm{hPa}$. Seasonally, lowlevel forcing is far larger in dry season than in wet season in South Asia, whereas the wet season forcing exceeds the dry season forcing in East Asia. The anthropogenic forcing in the present study is similar to that in Chung et al. (2005) in overall magnitude but the former offers fine-scale features and simulated vertical profiles. The interannual variability
\end{abstract}

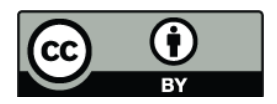

Correspondence to: C. E. Chung (eddy@gist.ac.kr) of the computed anthropogenic forcing is significant and extremely large over major emission outflow areas. Given the interannual variability, the present study's estimate is within the implicated range of the 1999 INDOEX result.

\section{Introduction}

Anthropogenic aerosols can modify climate directly by altering the radiative fluxes of the planet (Coakley and Cess, 1985; Charlson et al., 1991), and indirectly by altering cloud properties (Twomey, 1977; Albrecht, 1989, Rosenfeld, 2000). Total aerosol radiative forcing is defined as the effect of aerosol, both natural and anthropogenic, on the radiative fluxes at the top of the atmosphere (TOA) and at the surface and on the absorption of radiation within the atmosphere. Aerosols interact mainly with solar radiation, and the direct effect of aerosols on solar radiation, i.e., direct radiative forcing (DRF), has been estimated locally as well as globally in recent years.

A common procedure to estimate DRF is to use simulated aerosol distributions as input to a radiative transfer model. This procedure involves converting the simulated aerosol mass distributions into aerosol optical properties by empirical/theoretical algorithms, and then generate the DRF estimates using radiative transfer models. Kinne et al. (2003) summarized this procedure and also compared various aerosol simulations. The uncertainties in aerosol simulations arise from various factors including emission sources, meteorology and aerosol/chemistry processing (Kinne et al., 2003). An independent approach is to use observations of aerosol optical properties such as aerosol optical depth (AOD) and single scattering albedo (SSA) to compute DRF. Aerosol observations are now available from numerous

Published by Copernicus Publications on behalf of the European Geosciences Union. 
sources including field campaigns, aerosol observation networks and satellite retrievals. This approach has been implemented in Chung et al. (2005) ${ }^{1}$ and Yu et al. (2006).

Aerosol simulations offer spatially (X-Y-Z) and temporally continuous values, while aerosol observations offer presumably better accuracy. This study integrates these two approaches by using simulated aerosols that are nudged towards aerosol observations. This "aerosol observation assimilation" has been implemented earlier in Collins et al., 2001, and retains main advantages of both approaches. In this study, we attempt to improve the approach applied in Collins et al. (2005) study by a) employing a high-resolution regional climate model instead of a coarse-resolution global climate model and b) using ground and satellite retrieved aerosol observations. Giorgi et al. (2002), for example, adopted a regional model to simulate aerosols but did not assimilate aerosol data.

In our study, the regional climate simulation is constrained by global reanalyses throughout the model domain to provide atmospheric forcings for a regional scale chemistryaerosol model. In turn, the chemistry-aerosol model assimilates ground and satellite aerosol observations to simulate observationally constrained aerosol mass concentration and aerosol extinction coefficient. These simulated aerosols are incorporated in a radiative transfer model to estimate aerosol radiative forcing. In Sects. 2 and 3 of this paper, we describe this procedure overall, and we describe the aerosol forcing in detail in Sect. 4. Adhikary et al. (2008) described in detail the regional scale aerosol simulation in a parallel study.

The regional domain for our study is Asia. Asia contains about $60 \%$ of the world's population with rapid economic and industrial growth. It contributes about 30 to $50 \%$ of the anthropogenic aerosol burden and is a major source of black carbon in the atmosphere. Regional scale modeling is necessary to capture the spatial heterogeneity associated with orography and emissions in Asia, and to better resolve atmospheric processes and the interaction between aerosols and meteorological parameters.

\section{The Asian aerosol assimilation project}

The results in the present study are the products of a collaborative project between Scripps Institution of Oceanography (SIO), Pacific Northwest National Laboratory (PNNL), and the University of Iowa. As Fig. 1 illustrates, the PNNL regional climate model simulates meteorological variables that were used by the University of Iowa chemistry transport model STEM-2K1 (Sulfur Transport dEposition Model; version 2001) to simulate aerosol. The regional meteorological variables simulated by the PNNL model as well as the aerosol extinction coefficients simulated by the STEM-2K1

\footnotetext{
${ }^{1}$ substituted aerosol simulations in areas where aerosol observations were not available.
}

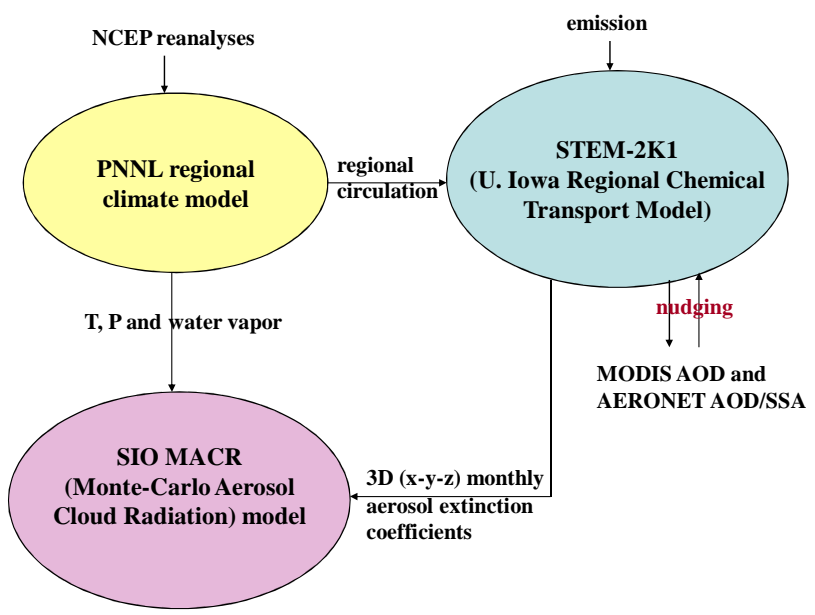

Fig. 1. Overview of the Asian aerosol assimilation project. The project has been a joint effort between Scripps Institution of Oceanography (SIO), Pacific Northwest National Laboratory (PNNL) and the University of Iowa. The SIO MACR (MonteCarlo Aerosol Cloud Radiation) model took aerosol simulations from Iowa STEM-2K1 (Sulfur Transport Deposition Model), meteorological variables from the PNNL regional model, and cloud from the ISCCP, so as to produce 2001-2004 aerosol radiative forcing.

were then used in the SIO Monte-Carlo Aerosol Cloud Radiation (MACR) model to simulate anthropogenic aerosol radiative forcing.

\section{1 (A) PNNL regional climate model}

The PNNL regional climate model is based on the Penn State/NCAR Mesoscale Model MM5 (Grell et al., 1995). The model has been used to simulate regional climate of the US (e.g., Leung et al., 2003; Gustafson and Leung, 2007) and East Asia (Leung et al., 2004; Qian and Leung, 2007), and found to generally well reproduce a wide range of climatic regimes in those regions. The model domain was expanded for this study. A major weakness, however, was found in simulating the interannual variations of the East Asian summer monsoon rainfall (Qian and Leung, 2007), which was related to model weaknesses in simulating the interannual variations of the large scale monsoon circulation in a large model domain. To ameliorate this problem, simple nudging was applied to constrain the large scale circulation of the regional model by a global reanalysis in this study. Similar to findings reported by others (e.g., von Storch, 2000; Castro et al., 2005), nudging was found to improve the anomaly correlation between the observed and simulated monthly mean precipitation, in addition to improving the variability of the simulated precipitation at the daily and diurnal time scales. The simulation, however, lacks precipitation in the Gangetic Plain, which is related to model weaknesses in simulating propagating mesoscale convective systems from the Bay of Bengal. 

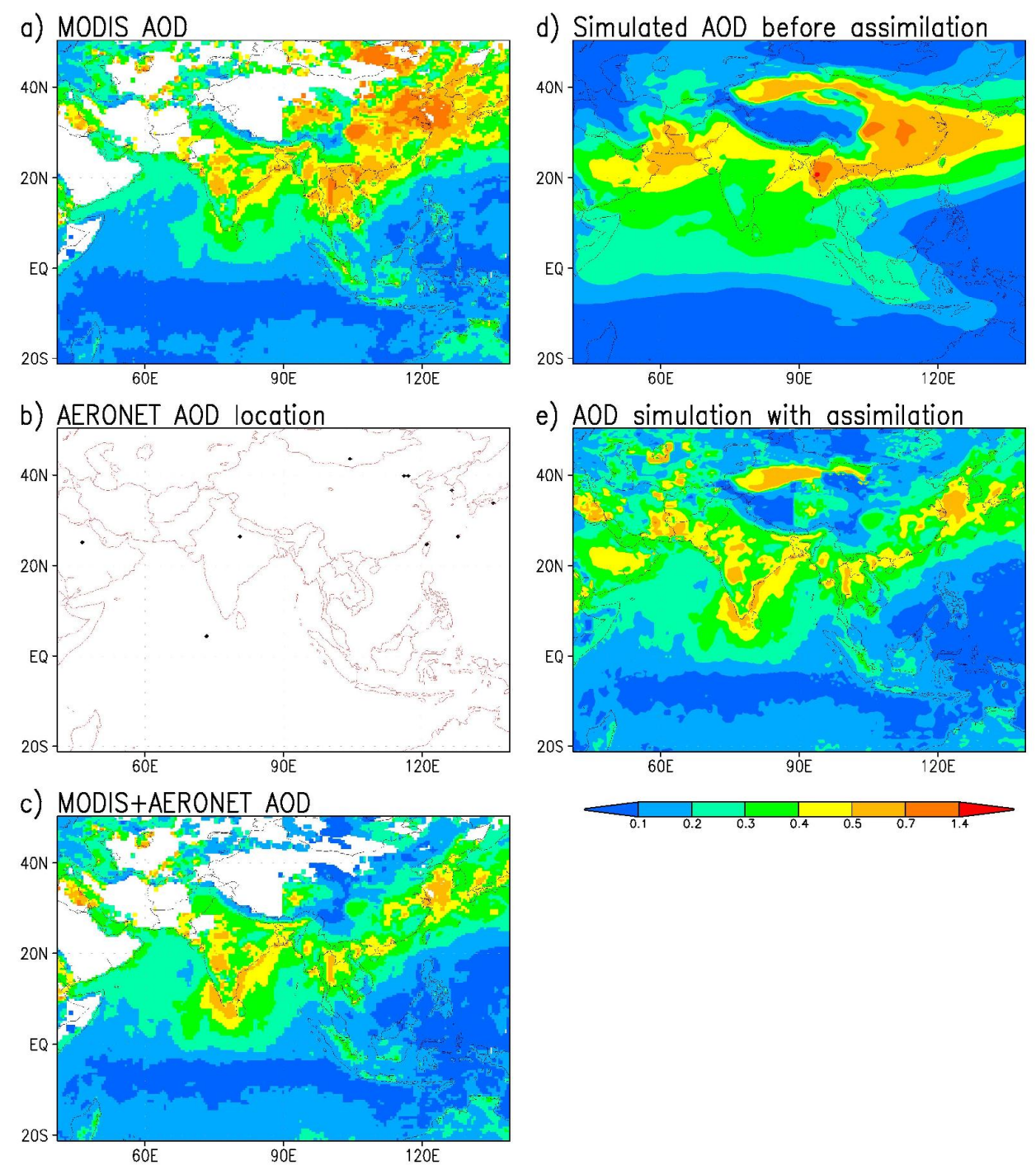

Fig. 2. Total (natural + anthropogenic) AOD (Aerosol Optical Depth). (a) Monthly AOD observation in March, 2001, from the satellite MODIS instrument. (b) Locations for monthly AERONET AOD data in March 2001. (c) March 2001 AOD adjusted with scattered ground observations AERONET. (d) Simulated AODs by the STEM-2K1 model (March, 2001). (e) AOD simulation after assimilating MODIS+AERONET AOD.

The regional climate model was applied at $60 \mathrm{~km}$ horizontal grid resolution with 23 vertical levels for the domain shown in Fig. 2. The regional climate simulation was initialized on 1 September 1998 and ran through 31 December 2005. The physics parameterizations used in this study include the Kain-Fritsch cumulus convection scheme (Kain and Fritsch, 1993), the Reisner mixed phase cloud microphysics scheme (Reisner et al., 1998), the Community Climate Model (CCM3) shortwave and longwave radiation scheme (Kiehl et al., 1994), a nonlocal boundary layer transfer scheme (Hong and Pan, 1996), and the Noah land surface model (Chen and Dudhia, 2001).
The simulation was driven by lateral boundary conditions and SSTs from the NCEP/NCAR global reanalysis (Kistler et al., 2001) using a simple relaxation scheme that blends the global reanalysis and the model solution over a 15 -grid point wide buffer zone in the lateral boundaries. To provide a larger constrain on the large scale circulation, winds and temperature simulated by the model were continuously nudged towards the global reanalysis throughout the domain. A nudging coefficient of $5 \times 10^{-5} \mathrm{~s}^{-1}$ was used between the simulated planetary boundary layer and the model top. Over the ocean, the nudging coefficient increases from zero at the surface to $5 \times 10^{-5} \mathrm{~s}^{-1}$ at the top of the boundary layer and remains constant above to allow nudging of winds and temperature throughout the atmospheric column. 
Three hourly outputs for all the three-dimensional meteorological variables and two-dimensional surface variables were archived to provide atmospheric conditions for driving the STEM-2K1 model (to be explained in the next subsection). Adhikary et al. (2007) used the same meteorological model outputs from this simulation for 2004-2005 to simulate aerosols over Asia. They evaluated the aerosol simulations against observations collected from the Atmospheric Brown Cloud-Post-Monsoon Experiment (ABC-APMEX) over two sites including the Kathmandu Observatory and the Hanimaadhoo Observatory in the Maldives. The regional climate model was found to provide realistic meteorological conditions for simulating aerosols over the two sites. Leung and Qian (2008) provide a more detailed evaluation of the regional climate simulation, particularly focusing on precipitation variations at the diurnal, seasonal, and interannual time scales.

\section{2 (B) U. Iowa STEM-2K1 model}

The Sulfur Transport dEposition Model (STEM-2K1) was used to generate the three-dimensional aerosol distributions from 2001 to 2004 . The model version used in this study was developed in 2001 and hence the model name STEM2K1. The STEM-2K1 has been extensively used previously to study aerosols and trace gases during this time period in South and Southeast Asia (Adhikary, et al., 2007; Carmichael, et al., 2003; Guttikunda, et al., 2005; Tang, et al., 2004). This is the first time that STEM-2K1 has been used to simulate aerosol mass concentration over multiple years such that average annual aerosol distribution with intra/interannual variability can be analyzed.

The STEM-2K1 for this study uses the PNNL regional model to drive the aerosol transport. The domain size and resolution of the STEM-2K1 model are the same as those of the PNNL model as in Fig. 2. In this study we have used the STEM-2K1 tracer model. All the aerosols are treated as externally mixed in STEM-2K1 tracer model. The model simulates the mass of sulfate, BC, OC, dust (fine and coarse) and sea salt (fine and coarse) aerosols. The dry deposition of aerosols was modeled using the "Resistance in Series Parameterization" (Wesley et al., 2000). The wet deposition of aerosols was calculated as a loss rate based on precipitation rate obtained from PNNL regional model. Further details of the wet scavenging and aerosol aging calculations can be found in Adhikary et al. (2007).

Anthropogenic emission inventory used in this study is primarily from the emission inventory developed for the 2001 NASA Transport and Chemical Evolution over the Pacific (TRACE-P) intensive field campaign (Streets et al., 2003). These emission estimates have been used extensively in Asian modeling studies and have been evaluated against data obtained in comprehensive field experiments (Huebert et al., 2003; Carmichael et al., 2003). Since this study domain is bigger than the TRACE-P domain, emission data from EDGAR database (Olivier and Berdowski, 2001) were used to fill the extended geographical areas.

The interannually varying emissions were not available for the 2001-2004 period studied in this paper. Since we constrained aerosol mass through AOD and SSA assimilations (described later in Sect. 3), any influence due to changes in emissions that are reflected in the observed AOD, should be reflected in our constrained aerosol distributions. We have studied and evaluated the impact of the interannual variability in meteorology and emissions on sulfur trends in Asia ( $\mathrm{Z}$. Lu et al., 2010) and this work indicates that during this time period that our constrained results did capture the observed trends in sulfur, with the meteorological variability contributing significantly to the observed variability in observed $\mathrm{SO}_{2}$ and sulfate.

Monthly varying emissions of carbonaceous aerosols from biomass burning are included in this study based on published emission datasets (var der Werf et al., 2006). The carbonaceous aerosol emissions from biomass burning used in this study were interpolated from $1^{\circ} \times 1^{\circ}$ resolution to the model domain. The emissions of sea salt are based on the parameterization of Gong (2003). Dust emissions are calculated online based on the methodology discussed by Tang et al. (2004). The emissions of carbonaceous and sulfate aerosols are assumed to be in the sub-micron range (diameter $<1 \mu \mathrm{m}$ ). Sea salt emissions are calculated for fine mode (less than $2.5 \mu \mathrm{m})$ and coarse mode $(2.5 \mu \mathrm{m}<$ diameter $<10 \mu \mathrm{m})$. Dust emissions are modeled using two size bins: submicron and super micron $(1<\mu \mathrm{m}$ diameter $<10 \mu \mathrm{m})$. Sulfate and sea salt aerosols are treated as a function of relative humidity while other aerosols are not. We did not include nitrates and secondary organics. In the case of nitrates it contributes less than $5 \%$ to the aerosol mass in Asia. We know that SOA (Secondary Organic Aerosol) can be an important source of aerosol mass. However the uncertainties in primary OC emissions as well as secondary production remain very large. We have compared our OC calculated values with OC and $\mathrm{OM}$ observations, and in terms of mass they are very consistent. We have included the hygroscopic growth based on OC, but do not include explicitly that portion due to SOA.

\section{3 (C) SIO MACR model}

3-D aerosol extinction coefficients for each aerosol specie simulated by the STEM-2K1 were averaged monthly as input for the Monte-Carlo Aerosol Cloud Radiation (MACR) model. The MACR model was originally developed and validated during the INDian Ocean EXperiment (INDOEX) (Satheesh et al., 1999; Podgorny et al., 2000; Podgorny and Ramanathan, 2001; Ramanathan et al., 2001) to compute solar fluxes and aerosol direct radiative forcing (DRF). Chung et al. (2005) upgraded the model (see their study for the model details). For this study, we further upgraded the model by i) adjusting spatial domain and vertical coordinate and ii) modifying gas absorption coefficients. Aerosol data 
other than aerosol extinction coefficients were computed as in Chung et al. (2005).

To account for cloud influences on aerosol radiative forcing, we took climatological cloud data from ISCCP (International Satellite Cloud Climatology Project) D2 product (Rossow and Schiffer, 1999), as in Chung et al. (2005), and then modified them using the MODIS cloud fraction (MOD08_M3). In this data integration, we used a higherresolution $\left(1^{\circ} \times 1^{\circ}\right)$ and year-to-year variations in MODIS overall cloud fraction, while retaining cloud separation into low, mid, high and deep convective, and cloud optical properties in ISCCP. Temperature and pressure fields were obtained from the PNNL regional model and monthly averaged for input. The MACR model was run to produce monthly aerosol forcing from 2001 to 2004. The anthropogenic portion was calculated by removing sea salt and dust contributions in aerosol extinction coefficients. The STEM-2K1 provides aerosol extinction coefficient for each aerosol species. Though treating all the dust particles as natural is a crude approximation, the overall errors from such an assumption appear small compared to other assumptions and approximations in the present study. We plan to refine our calculation in the future.

\section{Overview of aerosol data assimilation}

In this study, the STEM-2K1 aerosol simulation was nudged towards the observed aerosol data. Assimilated aerosol data are Daily Level 2 AOD products from MODIS (MODerate Imaging Spectro-radiometer; http://modis.gsfc.nasa. gov/) and monthly Level 2 AODs/SSAs from AERONET (AErosol RObotic NETwork; http://aeronet.gsfc.nasa.gov/). Daily MODIS data were converted into monthly values, and monthly AERONET/MODIS data were interpolated onto the STEM-2K1 resolution before assimilation. The accuracy of MODIS AODs was assessed in numerous studies by comparing MODIS AODS with AERONET AODs (Chung et al., 2005; Abdou et al., 2005; Ichoku et al., 2005). The accuracy of AERONET AODs was addressed by Eck et al. (1999) and Schmid et al. (1999). AERONET SSAs were compared with in-situ observations in studies such as Corrigan et al. (2008), Leahy et al. (2007), Johnson et al. (2009). Kim and Ramanathan (2008) found that MODIS aerosol data are accurate enough as input for radiative flux simulation within instrumental errors. Since AERONET observations are considered more accurate than MODIS observations, using MODIS and AERONET observations to nudge aerosol simulation appears acceptable for the scope of the present study.

MODIS onboard the Terra satellite gives near-global coverage on a monthly scale while AERONET is a ground based observation network. Spatially continuous monthly MODIS AODs and sparsely-distributed monthly AERONET AODs were integrated as in Chung et al. (2005), where the pattern of MODIS AODs was combined with AERONET AOD values. MODIS retrieved products also include fine mode AODs and coarse mode AODs. This size separation was also used for the present study. The large uncertainty in anthropogenic and natural emission estimates is one of the main motivations for constraining model-derived aerosol distributions with these aerosol observations. The MODIS and AERONET AODs reflect spatial and temporal (including interannual) variations in regional emissions (as well as transport and removal processes).

The aerosol data assimilation method is described in detail in Adhikary et al. (2008). The current study improved the assimilation procedure slightly and a summary is given here. MODIS and AERONET observations are assimilated with STEM-2K1 aerosol calculation using optimal interpolation technique initially developed for meteorological applications (Lorenc, 1986). The optimal interpolation methodology for assimilating satellite data has also been implemented in other chemical transport models such as ROSE (Research for Ozone in the Stratosphere and Its Evolution) and MOZART2 (Khattatov, et al., 2000). We implemented the optimal interpolation technique similar to the methodology described by Collins et al. for INDOEX aerosols using their MATCH model (Collins et al,, 2001). There are, however, some differences in our assimilation methodology, which are discussed later. First we present the mathematical relationship between the posterior aerosol distribution (analysis) with the model predicted aerosol (background) and satellite based observation (observation) in Eq. (1):

$\tau_{m}^{\prime}=\tau_{m}+\mathbf{K}\left(\tau_{o}-\mathbf{H} \tau_{m}\right)$.

$\tau_{m}^{\prime}$ is the posterior AOD while $\tau_{o}$, and $\tau_{m}$, are the observed and modeled AOD respectively. $\mathbf{K}$ is the Kalman gain matrix and $\mathbf{H}$ is a linear interpolator from model space to observation space. Since we have transformed the observed AOD into the STEM-2K1 model grid, the $\mathbf{H}$ matrix is simply the identity matrix. The $\mathbf{K}$ matrix is calculated based on the background and observation error covariance matrices and is defined by Eq. (2).

$$
\mathbf{K}=\mathbf{B H}^{T}\left(\mathbf{H B} \mathbf{H}^{T}+\mathbf{O}\right)^{-1}
$$

Here $\mathbf{B}$ and $\mathbf{O}$ are the error covariance matrices of the background and the observation fields respectively. Detailed discussion and assumption used to derive the $\mathbf{B}$ and $\mathbf{O s i m u l a t e d}$ absorbing and matrices are discussed by Collins et al. (2001). In Eqs. (3) and (4) we simply restate the mathematical relationship defining the $\mathbf{B}$ and $\mathbf{O}$ matrices and the values of the parameters that we have used in our assimilation process similar to the ones suggested for assimilating INDOEX aerosols.

$$
\mathbf{O}=\left(f_{o} \tau_{o}+\varepsilon_{o}\right)^{2} \mathbf{I}
$$


Here $\varepsilon_{o}$ (equal to 0.04) is the minimum Root Mean Square (RMS) error of the observation and $f_{o}$ (equal to 0.5) is the fractional error in observed AOD. I refers to identity matrix.

$\mathbf{B}(i, j)=\left(f_{m} \tau_{m}+\varepsilon_{m}\right)^{2} \exp \left[-\frac{d_{x}^{2}+d_{y}^{2}}{2 l_{x y}^{2}}\right]$

Here $\varepsilon_{m}$ is the minimum RMS uncertainty in the modeled AOD, which is set to 0.1 and $f_{m}$, the fractional error in the model AOD, is set to 0.5 . Variables $d_{x}$ and $d_{y}$ are the horizontal distance between two model grid points (equal to $50 \mathrm{~km})$ and $l_{x y}$ is the horizontal correlation length scale for errors in the model fields which is set to $250 \mathrm{~km}$ (five grid cells).

The methodology for generating the assimilated aerosol distributions is as follows. First, STEM-2K1 predicts three dimensional aerosol mass concentrations every three hours for all four years. This output is then averaged to produce monthly-mean three dimensional aerosol distributions. These distributions are then used to calculate AOD using aerosol chemical compound specific extinction cross sections at $550 \mathrm{~nm}$. The extinction cross section parameters used in STEM-2K1 are reported in Penner et al. (2001). The STEM-2K1 generated AODs are then used for assimilation of the AODs derived from MODIS observations, corrected with AERONET AODs as mentioned earlier. Our methodology differs from Collins et al. (2001) in that we also assimilate sea salt aerosol while their work chose to keep the modeled sea salt distribution fixed. Another difference in our assimilation technique is that we utilize both the coarse mode (total minus fine mode) and fine mode AOD available from MODIS. Due to the high uncertainty associated with MODIS fine mode fraction over land, we have limited the assimilation process to include the MODIS AOD fine mode fraction over ocean only. In this methodology, if there is no fine mode fraction available at a model grid point, then the assimilation is done only using total AOD. We chose to adjust the anthropogenic aerosols, namely sulfate, black carbon and organic carbon using the observed fine mode AOD, while dust and sea salt are adjusted based on the assimilated coarse mode AOD. We chose not to separate out sea salt and dust into fine and coarse modes in the assimilation step because of the large uncertainty associated with resolving the dust and sea salt into size bins based on effective radii. To avoid propagating this uncertainty further in the assimilation method, sea salt and dust were adjusted using coarse mode/total AOD. We have studied the sensitivity of our final results on this assumption and find that the results are essentially unchanged. At each time step and model layer the mass mixing ratios of the aerosols are adjusted by the ratios of monthly assimilated AOD to monthly simulated AOD.

Finally we used the available AERONET SSA data to adjust the absorbing aerosols (BC and dust). The simulated AOD products are calculated using aerosol optical properties at $550 \mathrm{~nm}$ wavelength. The simulated absorbing and scat- tering AOD values are calculated using empirical equations that take into account the scattering and absorbing characteristics of each aerosol specie, which are then used to calculate modeled SSA. We also found that the simulated SSA values were governed mostly by BC AOD. Since AERONET SSA is not available at $500 \mathrm{~nm}$, we interpolated the available AERONET SSAs at different wavelengths onto at $550 \mathrm{~nm}$, and compared it with simulated SSA. We found that the simulated SSA values showed a systematic positive bias averaging around $\sim 0.05$. We applied a SSA bias correction (0.05) for locations with total AOD $>0.3$ and dust AOD $<0.5$ across the whole domain. The effect of nudging the aerosol simulation towards AERONET SSA using this approach will be discussed later.

Figure 2 illustrates the overall assimilation procedure for March 2001. Monthly AODs from MODIS are shown in Fig. 2a. The MODIS AODs were corrected with AERONET AODs, referred to as "MODIS + AERONET AOD" for brevity here (Fig. 2c), as in Chung et al. (2005). Note that the number of AERONET sites in the domain changes from month to month from 4 to 22 . Figure $2 \mathrm{~b}$ displays AERONET sites that give AOD for March 2001. The STEM-2K1 simulated AODs before any aerosol data assimilation are displayed in Fig. 2d. After the assimilation, the final AODs are shown in Fig. 2e. The final AODs, which were used as input to the aerosol radiative forcing calculations as discussed next, appear similar to the MODIS+AERONET AODs where the latter are available. If both MODIS and AERONET data were missing for a grid cell, the predicted aerosol concentrations and AODs remained unchanged. Our data assimilation technique is in a way a tool for transition from MODIS+AERONET AOD areas to their gaps. Even in areas where MODIS+AERONET AOD exists, our assimilation technique provides additional valuable information such as aerosol vertical profiles and composition needed to accurately compute anthropogenic aerosol radiative forcing.

The forward model (before assimilation) predictions of AOD show that the STEM-2K1 model is able to capture many of the major features shown in the observed distributions, including high values over the major emission sources and outflow regions. March is a high dust month and the STEM-2K1 model for March 2001 shows high AOD over and downwind of the major dust source regions, including East Asia and the Middle East. The dust predictions for March and April of 2001 in East Asia have previously been discussed in detail, including comparison with observations of aerosol mass and composition obtained during the TRACE-P and ACE-Asia experiments (Tang et al., 2004a,b), where the simulations were shown to be reasonably consistent (within $\pm 30 \%$ ) with aircraft observations. After assimilation, the final AOD distribution closely matches the observation-based distributions.

In Fig. 3, the simulated and then nudged AODs in our study are compared to the GOCART (Georgiatech-Goddard Global Ozone Chemistry Aerosol Radiation and Transport) 
model (Chin et al., 2002) simulated AODs during MarchMay (MAM period). Our AODs produced with regional scale model and a formal assimilation procedure display more fine scale features than the GOCART AODs. In South Asia, aerosols trapped in the Indo-Gangetic valley are simulated in our study, and in East Asia, our simulated AODs are not dispersed as far towards Korea and Japan as are GOCART AODs. Figure 3 also displays MAM period AODs from Chung et al. (2005) which gives a previous observation-based estimate of aerosol radiative forcing. Chung et al. (2005) AODs resemble aspects of both the present study calculations and GOCART simulations. In next section, we will discuss the difference with Chung et al. (2005) estimates in detail and their impact on estimated aerosol radiative forcing.

The four-year mean assimilated model distribution of AOD is shown in Fig. 4. Also shown are the anthropogenic $\left(\mathrm{BC}+\mathrm{OC}+\mathrm{SO}_{4}\right) \mathrm{AOD}$ and $\mathrm{BC}$ AOD distributions, along with the $\mathrm{PM}_{10}$ surface mass concentration averaged over the study period. The anthropogenic contribution from fossil and biofuel combustion dominates over most of Asia as seen from the high anthropogenic and BC AOD values at locations around heavily populated and industrialized areas including Indo-Gangetic plain and East China. The open biomass burning is the major contributor to the high values of anthropogenic AOD seen over Southeast Asia. The largest impacts of dust and its outflow can be seen clearly in the high $\mathrm{PM}_{10}$ concentrations over the Middle East and Western China. A distinguishing feature of Asia is a large contribution of $\mathrm{BC}$ to total AOD throughout much of Asia. Using AODs from Chung et al. (2005), we find that BC in Asia $\left(60-138^{\circ} \mathrm{E}\right.$ and Equator $-45^{\circ} \mathrm{N}$ ) is about 3 times as large as global mean BC while total aerosol AOD in Asia is only 2 times as large as global mean AOD.

An evaluation of the STEM-2K1 model skill in the forward mode in calculating AOD and aerosol mass concentrations and composition against a year long data set for 2005 available from the ABC project and an AERONET site in South Asia is presented in Adhikary et al., (2007). The model was shown to be able to capture the seasonal trends and magnitude of the observed AOD at both the Kanpur and Hanimaadhoo sites. This study also reported that the STEM2K1 modeled fine to coarse mode aerosol mass ratio agreed with the seasonal variation of observed angstrom exponent (an indicator of aerosol size) at Hanimaadhoo. An evaluation of the STEM-2K1 assimilated distributions along with an analysis of their sensitivity to the optimal interpolation technique was presented in detail in Adhikary et al. (2008). In the present study, we have used the same optimal interpolation technique with minor modifications. Illustrative results are shown in Fig. 5, where computed AOD and surface $\mathrm{PM}_{10}$ are compared with observations. Observations in Fig. 5 are from AERONET AODs, MODIS AODs and EANET PM. The AERONET AOD data for 2001-2004 period used in this assimilation were downloaded from the AERONET website in the year 2005. The most recent data for the same 20012004 period (accessed in October 2009 from the AERONET website) have updated and expanded values and this newer AERONET AOD data are referred to as "AERONET-new" in Fig. 5. In this study, we chose not to include the "AERONET new" in the assimilation process and instead use it as an independent data set to evaluate the assimilation results.

As seen in Fig. 5, the assimilated AOD distributions are shown to capture the seasonal variability over a wide range of conditions from sites dominated by wind blown dust (Al Dhafra), to sites at island locations in the outflow from major continents (Male and Okinawa), to sites in major urban areas (Kanpur and Chulalongkorn). The computed surface $\mathrm{PM}_{10}$ is compared to available observations from the $\mathrm{ABC}$ project and the EANET (2004) monitoring network. The 4-year annual $\mathrm{PM}_{10}$ distribution is shown in Fig. 4, where high $\mathrm{PM}_{10}$ values are found throughout Asia as a result of wind blown dust, open burning and anthropogenic activities. The $\mathrm{PM}_{10}$ observations are rather limited during these years; however the model is able to capture regional differences and variability over a wide geographical area. Additional discussion of the aerosol composition and the component contributions to AOD in these computed fields are available in Carmichael et al., (2009).

Of particular interest from a radiative forcing perspective is the estimation of $\mathrm{BC}$ distributions and AOD. A comparison of predicted surface $\mathrm{BC}$ mass concentrations at $\mathrm{ABC}$ sites has been presented and discussed in Adhikary et al., (2007), where the model was shown to accurately predict the BC observed at Hanimadhoo (seasonality and magnitude), and to underpredict peak values in Kathmandu. Recently BC estimates using global aerosol models have been compared with observations under the AeroCom project (Koch et al., 2009). In general, the BC mass and AOD predicted by these models for the Asia sub-domain were found to be biased low by a factor of two. Our assimilated field of BC AOD shown in Fig. 4, which takes into consideration AERONET SSA in the assimilation, compares well with the AERONET and OMI derived absorption AOD (AAOD) (see Fig. 3 Koch et al., 2009). For example, the AAODs from AERONET are in the 0.02 to 0.03 range in the outflow regions around India and China, and above 0.05 in the Indo Ganges plain, and in the China megacity influenced regions around Beijing, Shanghai and the Pearl River Delta.

The OMI data was not available for the 2001-2004 period studied in this paper as OMI was launched only in 2004. So we could not compare our results with OMI. However, we have compared the simulated AOD values to the available AERONET products during the study period. Figure 6 shows the comparison of various AERONET products including AOD, coarse/fine mode AOD, SSA and AAOD at Kanpur. It is important to note that the assimilation process did not include the AERONET AOD at Kanpur and therefore provide an independent evaluation of the model prediction skills. The AOD (total, coarse, fine) values used here correspond to 

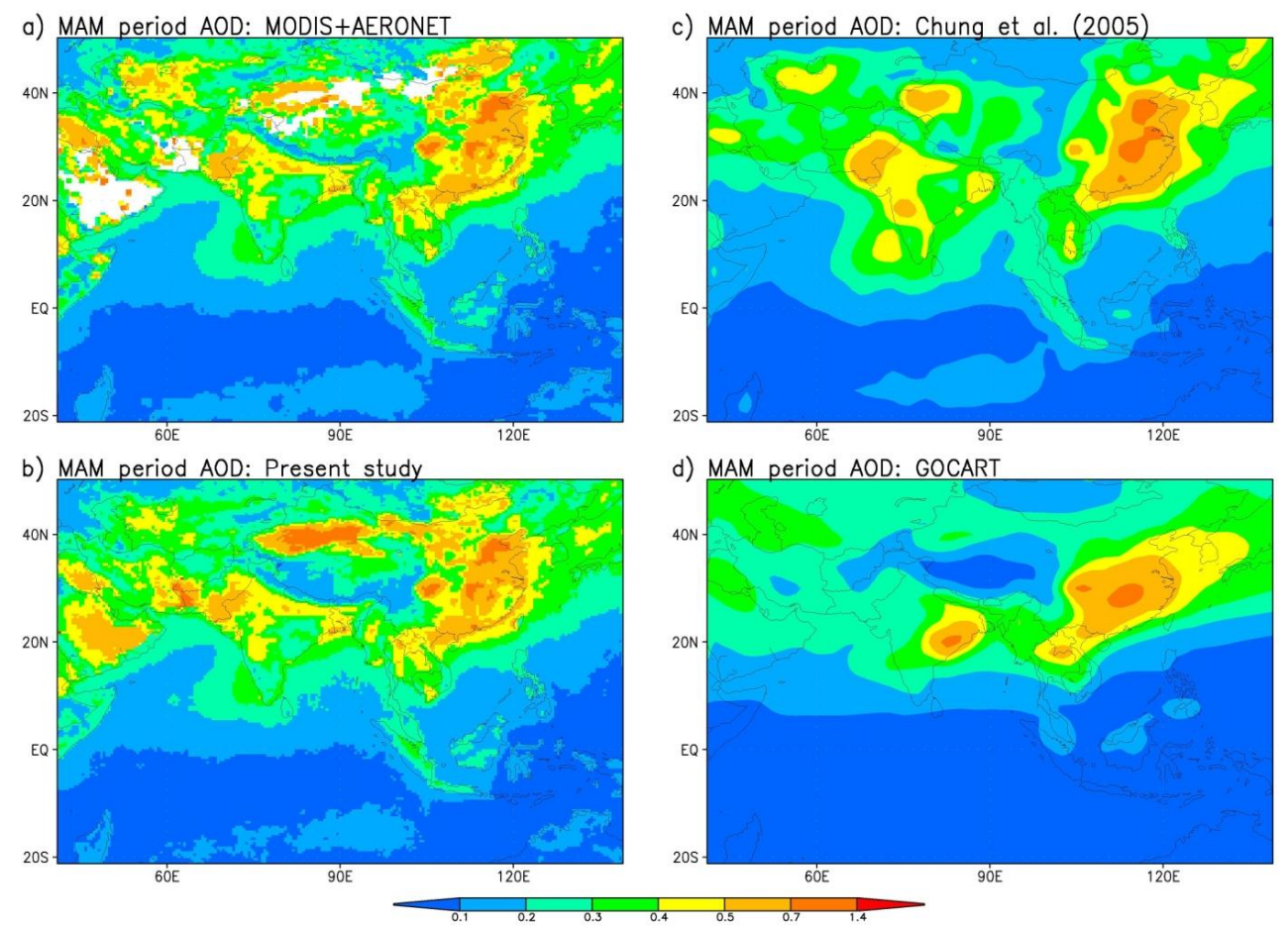

Fig. 3. Total (natural + anthropogenic) AOD simulation in comparison with that in Chung et al. (2005) and the GOCART AOD simulation (on $2.5^{\circ} \times 2^{\circ}$ ). AERONET/MODIS integrated AODs are also shown (a). Note that our simulation is 2001-2004 mean while Chung et al. (2005) calculation was for 2001-2003 and the GOCART simulation is averaged from 2000 to 2002.

$500 \mathrm{~nm}$, while the observed SSA and AAOD were interpolated. The modeled values (at $550 \mathrm{~nm}$ ) are able to capture the seasonality and variability seen in the observed AOD in all modes, but with a low bias. For example the model underpredicts the peak AOD values seen around April-May 2003, which represents the peak dry season associated with high dust emissions. Another instance is the underprediction of fine mode AOD during the post monsoonal period (September through December). Our predicted SSA at $550 \mathrm{~nm}$ is biased high by $\sim 0.03$ and the corresponding AAOD values are biased low by $\sim 25 \%$ with maximum bias during the post monsoonal period, which is consistent with the trend seen in fine mode AOD.

To further verify the simulated aerosol in this study beyond AOD, we examine BC (Black Carbon) concentration vertical structures in Fig. 7. BC vertical structure is an extremely important component of aerosol data in calculating anthropogenic aerosol radiative forcing and 3-D aerosol heating rate. From 6 to 31 March 2006, Maldives Autonomous UAV (Unmanned Aerial Vehicle) Campaign (MAC Campaign) took place (Ramana et al., 2007; Corrigan et al., 2008; Ramanathan et al., 2007). The MAC yielded BC concentration vertical structures over $73.18^{\circ} \mathrm{E} \& 6.78^{\circ} \mathrm{N}$ in most of March 2006, and we calculated the monthly mean. Figure 7 compares the $\mathrm{BC}$ data from the MAC with the present study calculation at a nearby grid. First, it is encouraging that the observed BC concentration magnitude is approximately in the simulation range. Second, the observed monthly $\mathrm{BC}$ is maximum around 1500-2000 m height as a result of blending boundary layer aerosol structure data and lifted aerosol structure data. In other words, MAC observations for each flight show either a boundary-layer structure or lifted aerosol structure, and monthly mean mix these two profiles. The simulated BC vertical profile at a nearby grid, however, tends to show boundary-layer concentrated structures. On the other hand, the simulated BC concentration near the surface is not particularly stronger than the simulated concentrations above the boundary layer. Third, there is a large interannual variation of $\mathrm{BC}$ concentration at this location. The profiles presented in this figure have to be carefully considered. The UAV profiles for several days are presented as a monthly average and compared with a monthly mean profiles derived from the model. The model results for multiple years show that the interannual variability due to meteorology on the amount of BC reaching this location is very large. For 2003 March, we show more clearly the variability in vertical profiles within the month by plotting profiles for a few specific days in March. We see that during certain periods the model does produce profiles with vertical structure with $\mathrm{BC}$ maximums in layers $2-3 \mathrm{~km}$ above the surface. More discussion on interannual variability follows in the later sections. 

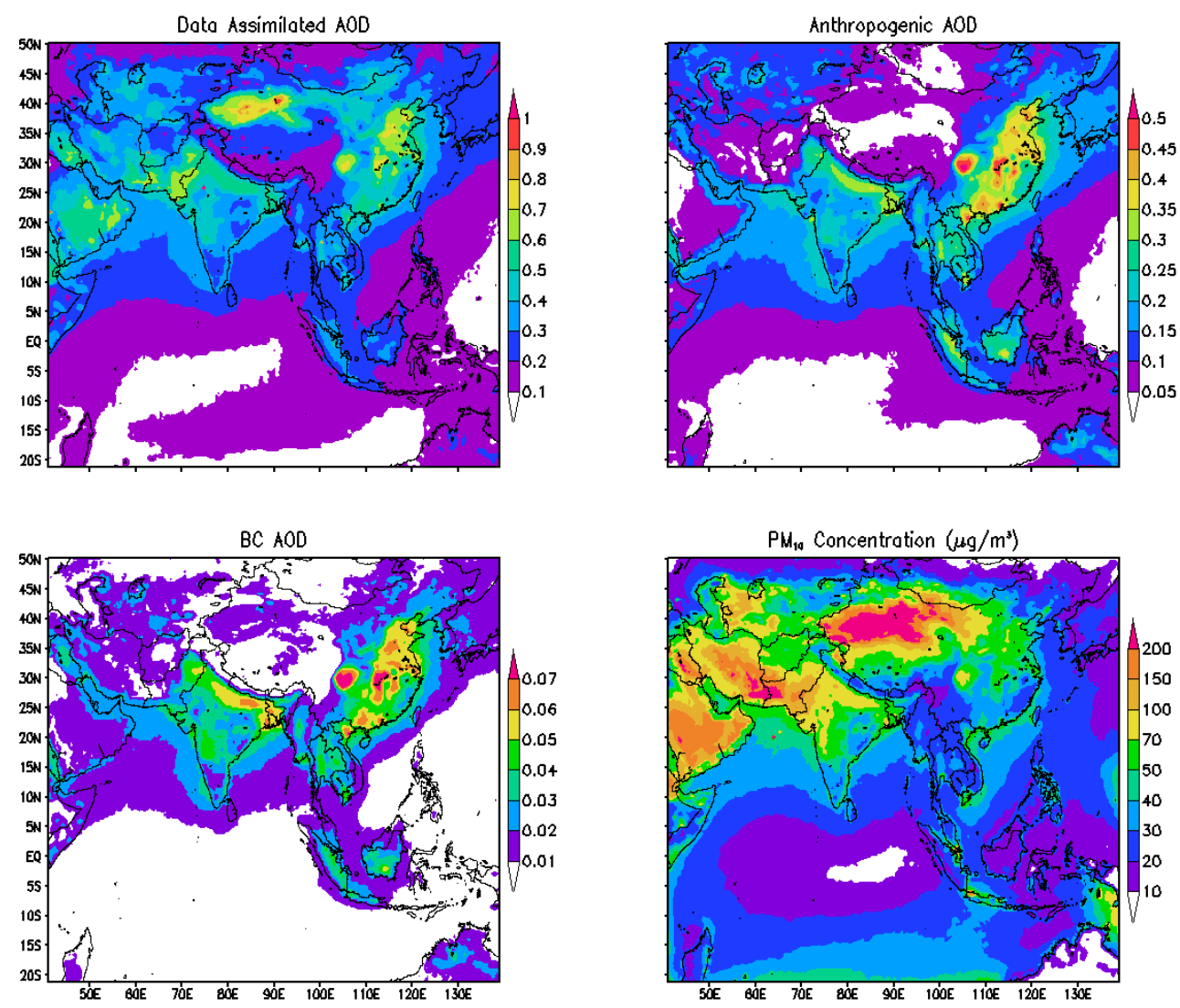

Fig. 4. Four-year mean model fields after assimilation of AOD, anthropogenic AOD, BC AOD and surface $\mathrm{PM}_{10} \mathrm{mass}_{\mathrm{s}}$ concentration $\left(\mu \mathrm{g} / \mathrm{m}^{3}\right)$.

\section{Anthropogenic aerosol forcing}

The SIO MACR model was used to convert aerosol extinction coefficients into aerosol radiative forcing. The anthropogenic portion of the computed direct aerosol radiative forcing is shown in Fig. 8 and subsequent figures. In these figures, forcing estimates are for all skies and not for clear skies.

Figure 8 displays the 2001-2004 averaged forcing at the surface, in the atmosphere and at the top of the atmosphere (TOA). $\mathrm{F}(\mathrm{TOA})$, i.e., aerosol forcing at the TOA, is negative for the entire domain (Fig. 8a). Negative values are particularly pronounced in the northern Indian Ocean. $\mathrm{F}(\mathrm{S})$ (forcing at the surface) and F(A) (forcing in the atmosphere) have comparable magnitudes and opposite signs. As a result, $F(S)$ and $\mathrm{F}(\mathrm{A})$ are much larger than $\mathrm{F}(\mathrm{TOA})$ in magnitude, since $\mathrm{F}(\mathrm{TOA})=\mathrm{F}(\mathrm{S})+\mathrm{F}(\mathrm{A}) . \mathrm{F}(\mathrm{S})$ mirrors $\mathrm{F}(\mathrm{A})$ except over the Persian Gulf. $F(S) / F(T O A)$ as in Fig. 8d shows the relative importance of atmospheric forcing. In South Asia and most coastal areas, $\mathrm{F}(\mathrm{S}) / \mathrm{F}(\mathrm{TOA})$ is noticeably large.

Chung et al. (2005) also estimated direct anthropogenic aerosol forcing by using MODIS + AERONET AODs and AERONET SSAs. Recently, Myhre (2009) evaluated global direct aerosol forcing estimates in IPCC Assessment Report IV and placed Chung et al. (2005) estimate at the best ac- curacy. The present study differs from Chung et al. (2005) in many respects. Aerosol data assimilation in the present study was used to deal with data gaps and provide vertical structures while Chung et al. assumed uniform vertical aerosol profiles and used GOCART aerosol simulation to fill the gaps. Plus, this study employed high-resolution models. The comparative outputs of the current study and Chung et al. (2005) are summarized in Table 1. Averaged over Asia $\left(60-138^{\circ} \mathrm{E} \&\right.$ Equator- $\left.-45^{\circ} \mathrm{N}\right)$, the present study finds the TOA forcing to be $-1.3 \mathrm{~W} / \mathrm{m}^{2}$ in comparison with $-1.1 \mathrm{~W} / \mathrm{m}^{2}$ from Chung et al. (2005). In the atmosphere, this study yields $+7.3 \mathrm{~W} / \mathrm{m}^{2}$ while Chung et al. gives $+8.0 \mathrm{~W} / \mathrm{m}^{2}$. Removing cloud, we obtained clear-sky forcing estimates as well. The present study gives $-4.2 \mathrm{~W} / \mathrm{m}^{2}$ for TOA forcing when Chung et al. (2005) gave $-2.3 \mathrm{~W} / \mathrm{m}^{2}$, indicating that using MODIS cloud increases anthropogenic aerosol forcing at TOA over ISCCP cloud.

We repeated the MACR model without the BC component in order to calculate the $\mathrm{BC}$ radiative forcing. We did this, given accelerating interests in the role of $\mathrm{BC}$ since $\mathrm{Ra}$ manathan and Carmichael (2008) reported the global direct BC TOA forcing to be $+0.9 \mathrm{~W} / \mathrm{m}^{2}$ using Chung et al. (2005) calculations. Note that the global anthropogenic $\mathrm{CO}_{2}$ forcing is only about $1.6 \mathrm{~W} / \mathrm{m}^{2}$ (IPCC Assessment Report IV; 

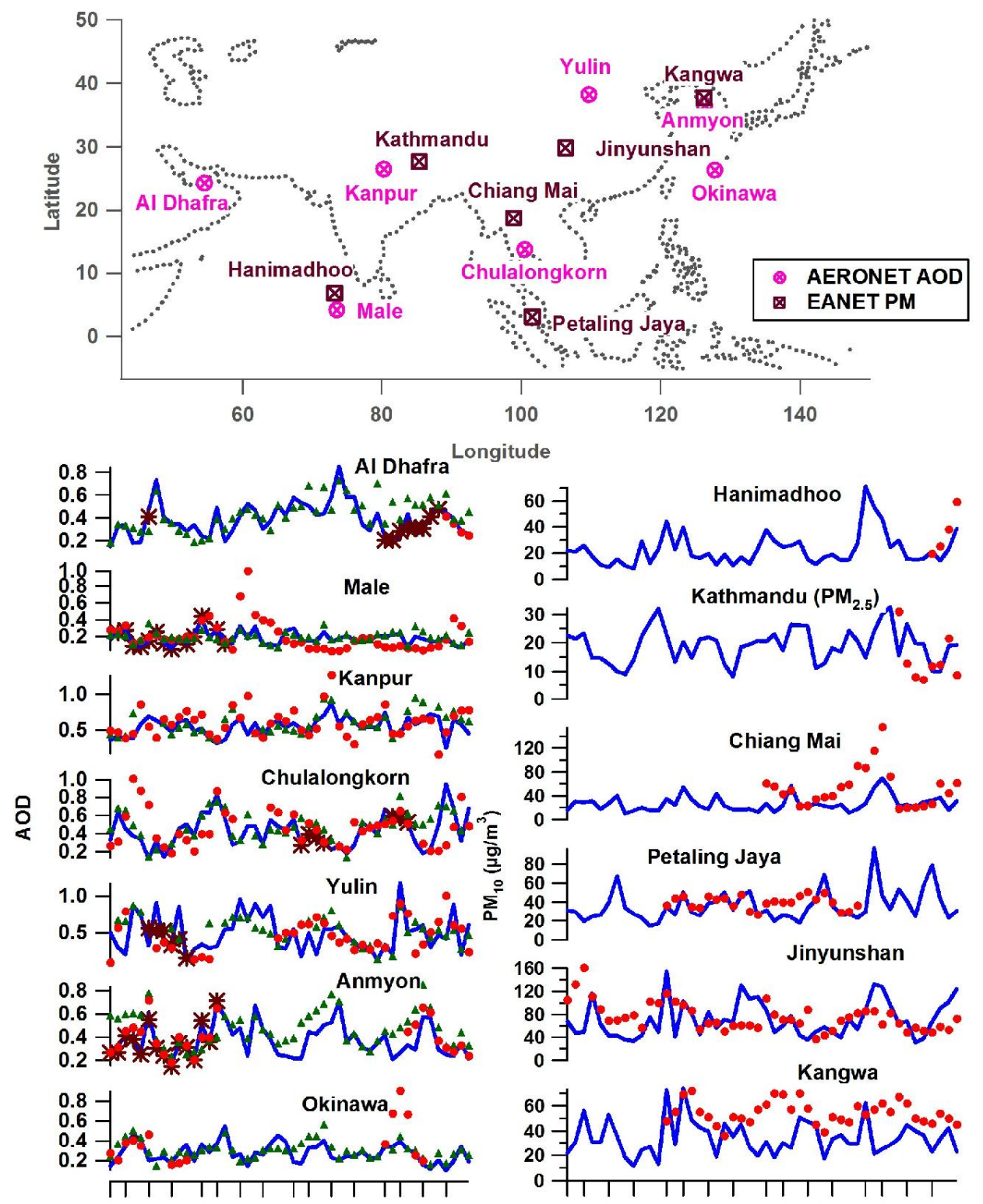

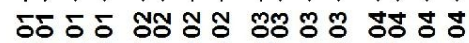

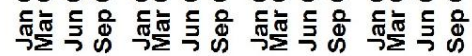

* Aeronet used in assimilation

- Aeronet new $\triangle$ MODIS - Assimilated
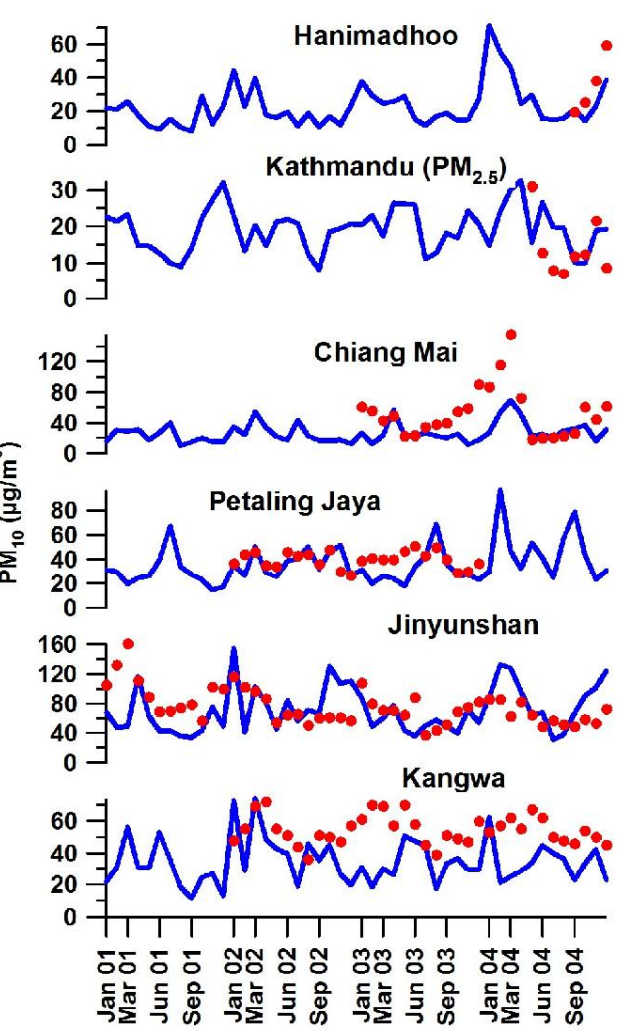

Fig. 5. AOD (left panels) and surface $\mathrm{PM}_{10}$ mass concentration (right panels). Modeled AOD and PM10 concentration after assimilation, in comparison with MODIS and AERONET AODs and EANET PM10 observations at selected sites. The AERONET AODs used in the assimilation are also shown. The AERONET new denotes the AOD values used for evaluation of the model prediction skills. Further details of the "AERONET new" are described in the text.

Ramanathan and Carmichael, 2008). Using ECHAM5, we obtained anthropogenic $\mathrm{CO}_{2}$ forcing to be close to $1.6 \mathrm{~W} / \mathrm{m}^{2}$ as averaged in Asia. Our current BC TOA forcing estimate in Asia is $+2.1 \mathrm{~W} / \mathrm{m}^{2}$ when Chung et al. gives $+2.3 \mathrm{~W} / \mathrm{m}^{2}$. Over Asia both estimates give $\mathrm{BC}$ forcing larger than anthropogenic $\mathrm{CO}_{2}$ forcing.
The fact that the present study and Chung et al's (2005) give very similar estimates despite a number of different steps taken indicates that aerosol observation is the primary importance in calculating direct aerosol forcing. To be sure, we computed anthropogenic aerosol forcing without using AERONET SSAs also, and obtained surprisingly 
Table 1. Aerosol radiative forcing averaged in Asia $\left(60-138^{\circ} \mathrm{E}\right.$ and Equator $\left.-45^{\circ} \mathrm{N}\right)$. This table compares the present study's calculations with those derived from Chung et al. (2005). Both studies used the MODIS and AERONET aerosol observations while the primary differences are i) aerosol vertical profile simulated by a high-resolution model in this study (as opposed to a prescribed uniform aerosol profile in Chung et al., 2005), ii) different aerosol-chemistry models used to fill up aerosol data gaps, and iii) different cloud observations.

\begin{tabular}{lllllll}
\hline & $\begin{array}{l}\text { Present study } \\
\text { (anthropogenic } \\
\text { aerosol) }\end{array}$ & $\begin{array}{l}\text { Present study } \\
\text { (clear sky; } \\
\text { anthropogenic } \\
\text { aerosol) }\end{array}$ & $\begin{array}{l}\text { Present study } \\
\text { (BC aerosol) }\end{array}$ & $\begin{array}{l}\text { Chung et al. } \\
(2005) \\
\text { anthropogenic } \\
\text { aerosol) }\end{array}$ & $\begin{array}{l}\text { Chung et al. (2005) } \\
\text { (clear sky; anthro- } \begin{array}{l}\text { Chung et al. } \\
\text { pogenic aerosol) }\end{array}\end{array}$ \\
\hline TOA & $-1.3 \mathrm{~W} / \mathrm{m}^{2}$ & -4.2 & +2.1 & -1.1 & -2.3 & +2.3 \\
Atmosphere & +7.3 & +8.1 & +7.3 & +8.0 & +9.4 & +7.6 \\
Surface & -8.6 & -12.3 & -5.2 & -9.1 & -11.7 & -5.3 \\
\hline
\end{tabular}

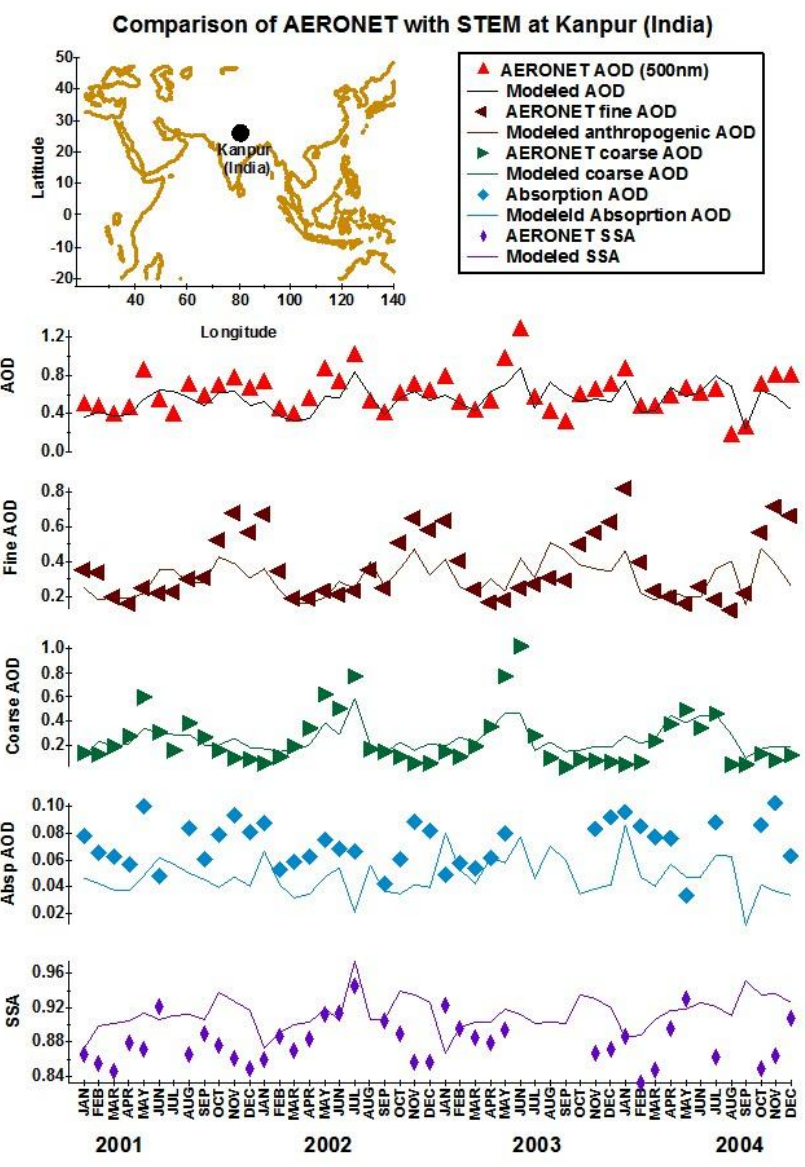

Fig. 6. Comparison of AERONET products with the simulated values at Kanpur India during the 2001-2004 study period. All the AERONET products except SSA and AAOD are obtained at $500 \mathrm{~nm}$. The observed AAOD and SSA are interpolated values. The modeled values are obtained at $550 \mathrm{~nm}$. The modeled anthropogenic AOD denotes sum of $\mathrm{SO} 4+\mathrm{BC}+\mathrm{OC}$ AODs.

less $\mathrm{BC}$ concentration. As a result, the Asia-averaged anthropogenic aerosol forcing was $-2.3 \mathrm{~W} / \mathrm{m}^{2}$ at TOA, $+4.5 \mathrm{~W} / \mathrm{m}^{2}$ in the atmosphere and $-6.8 \mathrm{~W} / \mathrm{m}^{2}$ at the surface without us-

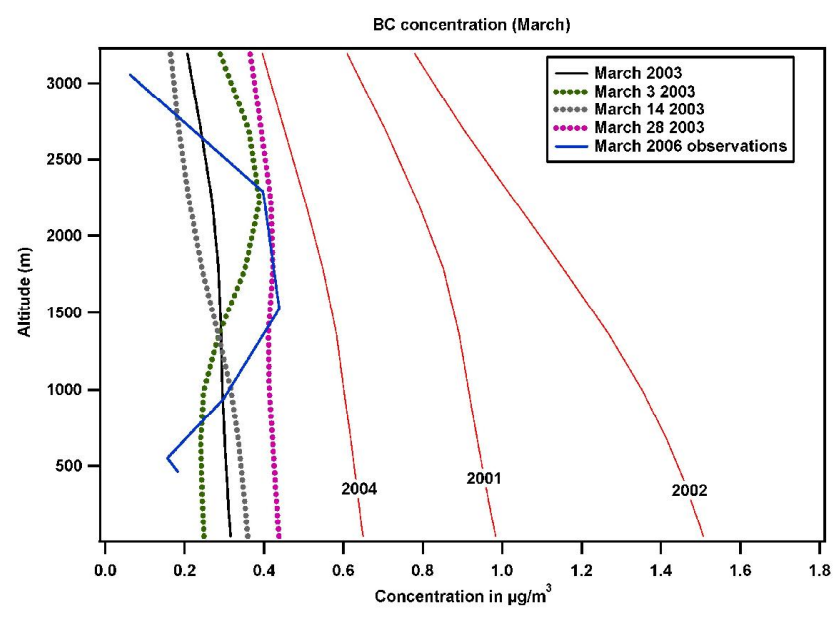

Fig. 7. Monthly BC (black carbon) concentration comparison (in units of $\mu \mathrm{g} / \mathrm{m}^{3}$ ). Blue line displays the MAC observation data over $73.18^{\circ} \mathrm{E}$ and $6.78^{\circ} \mathrm{N}$ during March 2006 (Ramanathan et al. 2007). Red lines show the present model calculation at a nearby grid $\left(73.36^{\circ} \mathrm{E}\right.$ and $\left.6.6^{\circ} \mathrm{N}\right)$ in March 2001, March 2002, March 2003 and March 2004, respectively.

ing AERONET SSAs. BC forcing was $+1.2 \mathrm{~W} / \mathrm{m}^{2}$ at TOA, $+4.4 \mathrm{~W} / \mathrm{m}^{2}$ in the atmosphere and $-3.2 \mathrm{~W} / \mathrm{m}^{2}$ at the surface, compared with $+2.1 \mathrm{~W} / \mathrm{m}^{2}$ at TOA, $+7.3 \mathrm{~W} / \mathrm{m}^{2}$ in the atmosphere and $-5.2 \mathrm{~W} / \mathrm{m}^{2}$ at the surface with AERONET SSAs in Table 1. This sensitivity test relfects the growing importance of using aerosol absorption observation to constrain the simulated distributions. The results with AERONET SSAs are what we consider more accurate and are reported in the figures. However it should be noted that the simulated SSA (after assimilation and SSA bias correction) are still biased high when compared to observations at Kanpur as seen in the Fig. 6, suggesting that the adjusted absorbed AOD could lead to conservative estimates of forcing calculated by radiative transfer model.

Figure 9 shows $\mathrm{F}(\mathrm{A})$ at $775 \mathrm{hPa}$ in the months of January, April, July and October. F(A), i.e., aerosol forcing in the 

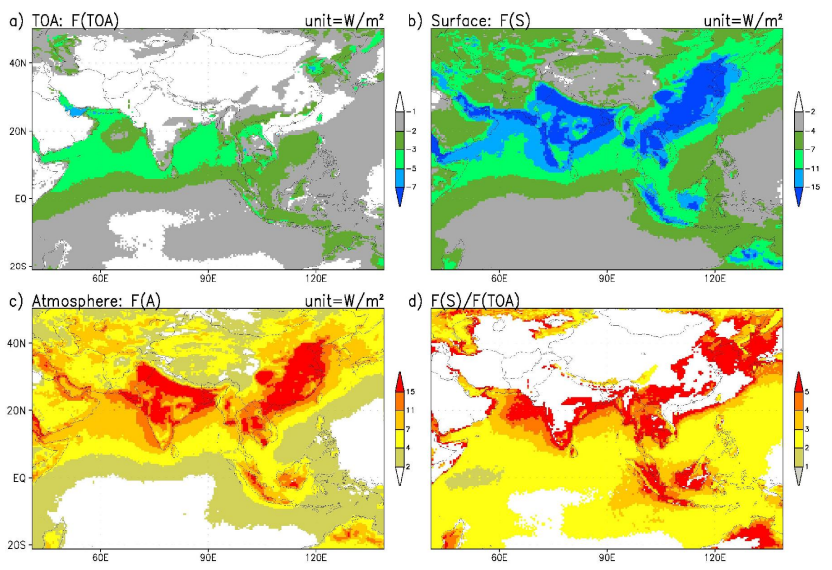

2001-2004 average

Fig. 8. Anthropogenic direct aerosol radiative forcing averaged over the entire 2001-2004 period. In this and subsequent figures, the forcing estimates are for cloudy skies.
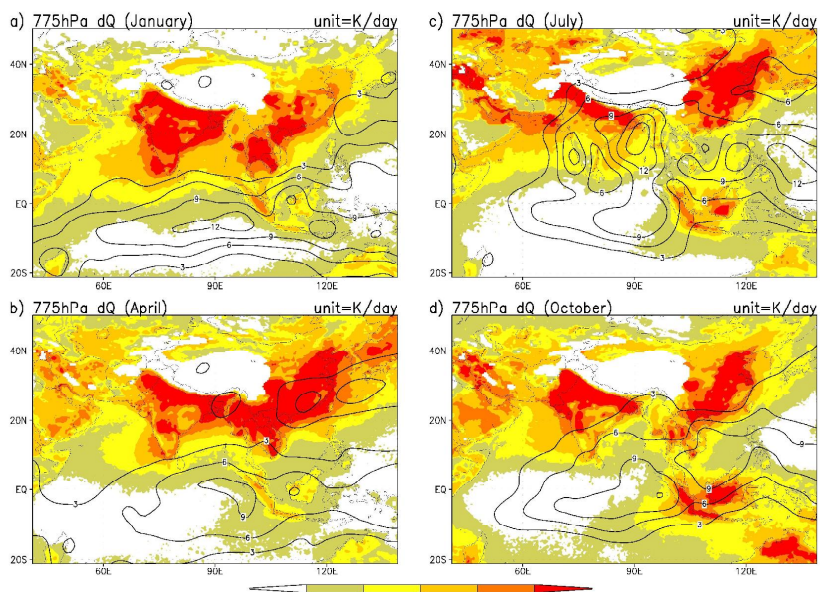

Fig. 9. Monthly anthropogenic aerosol radiative forcing averaged from 2001 to 2004. Contours are observed climatological precipitation in units of $\mathrm{mm} /$ day. Note that the PNNL model precipitation simulation in this study is similar to the observation in pattern.

atmosphere, is another source of diabatic heating and is able to burn low-level clouds and/or disturb atmospheric circulation quickly. $775 \mathrm{hPa} \mathrm{F}(\mathrm{A})$ varies from almost zero to 1.0 $\mathrm{K} /$ day or more, and as such exhibits strong spatial gradients. Superimposed on F(A) in Fig. 9 are contours representing climatological precipitation derived by Xie and Arkin (1996). $\mathrm{F}(\mathrm{A})$ maximum tends to be located away from highly precipitating areas, but notable exceptions include $\mathrm{F}(\mathrm{A})$ over the Indo-Gangetic valley in July. In spite of monsoon precipitation, aerosol concentration is large over there, because of week to two weeks long monsoon breaks (intervals between rain events).

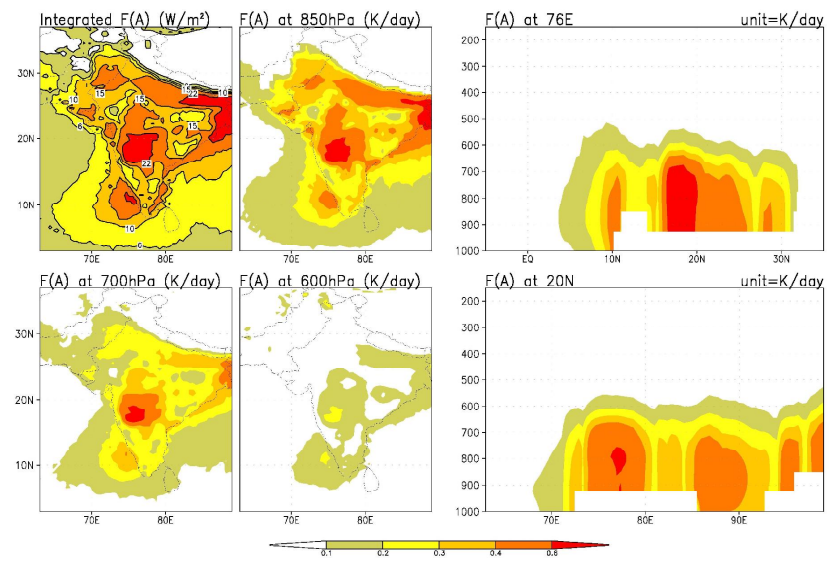

Fig. 10. Anthropogenic aerosol forcing in the atmosphere for February (averaged from 2001 to 2004).

Figure 10 displays the vertical structure of $\mathrm{F}(\mathrm{A})$ in South Asia in February. F(A) at $850 \mathrm{hPa}$ and $\mathrm{F}(\mathrm{A})$ at $700 \mathrm{hPa}$ appear similar with different magnitudes. Vertical cross sections at $76^{\circ} \mathrm{E}$ and at $20^{\circ} \mathrm{N}$ show most of the forcing between the surface and $600 \mathrm{hPa}$ with maximum around $800 \mathrm{hPa}$. It is interesting to note that maximum aerosol heating rate is of ten located far above the surface when the simulated aerosol concentration is largest near the surface. To our belief, this is because absorbing aerosols above low-level clouds lead to larger solar heating rate than the same aerosols below clouds. Note that simulated aerosol concentration near the surface is only slightly larger than those between 800 and $900 \mathrm{hPa}$. If aerosol concentration is uniform vertically as assumed in Chung et al. (2005), aerosol solar heating rate would have conspicuous maximum values around $800 \mathrm{hPa}$. As seen from Fig. 7, observed aerosol concentration peaks above $1 \mathrm{~km}$ over Maldives. This would lead to a very large aerosol solar heating rate above $1 \mathrm{~km}$. The importance of aerosol solar hearing rate vertical profile in affecting surface temperature and precipitation was examined by Chung and Zhang (2004) who demonstrated that climatic effects of absorbing aerosols are very sensitive to the vertical profile of aerosols. The vertical structure of $\mathrm{F}(\mathrm{A})$ in East Asia is quite similar to that in South Asia (Fig. 11).

Figures 12-13 demonstrate year-to-year variability of $\mathrm{F}(\mathrm{S})$ (aerosol forcing at the surface) in South Asia and East Asia. The interannual variability in $\mathrm{F}(\mathrm{S})$ is quite sizable, and very large in some areas. Averaged over $40-100^{\circ} \mathrm{E} \&$ Equator $-20^{\circ} \mathrm{N}$, January-March average of $\mathrm{F}(\mathrm{S})$ fluctuates from $-6.2 \mathrm{~W} / \mathrm{m}^{2}$ (2004) to $-14.7 \mathrm{~W} / \mathrm{m}^{2}$ (2002), giving the 4 year mean $-11.1 \mathrm{~W} / \mathrm{m}^{2}$ (Table 2 ). At a single grid point, interannual variability can be even greater, as seen in Fig. 6 . Interannual variability is also large in East Asia (Fig. 13). The Yellow Sea and East Sea (i.e., Sea of Japan) areas show very large interannual variability but not the eastern China where there is a lot of industrial capacity. Similarly, over 
Table 2. Anthropogenic aerosol radiative forcing averaged over the INDOEX domain $\left(40-100^{\circ} \mathrm{E}\right.$ and Equator-20 $\left.\mathrm{N}\right)$ for the JanuaryMarch period. The forcing estimate for the year 1999 from the INDOEX (Indian Ocean Experiment) is shown along with Chung et al. (2005) estimate for 2001-2003, the present study's estimate for 2001-2004 and the CCSM calculation. For the present study's estimate, we also show the range from an estimate for each year.

\begin{tabular}{lllll}
\hline & INDOEX results (Ramanathan et al. 2001) & Chung et al. (2005) & Present study & NCAR/CCSM3 \\
\hline TOA & $-2.5 \sim+0.5 \mathrm{~W} / \mathrm{m}^{2}$ & -2.9 & $-3.6(-4.5 \sim-1.9)$ & -1.1 \\
Atmosphere & & +7.6 & $+7.6(+4.3 \sim+10.4)$ & +4.5 \\
Surface & $-18 \sim-14$ & -10.5 & $-11.1(-14.7 \sim-6.2)$ & -5.6 \\
\hline
\end{tabular}
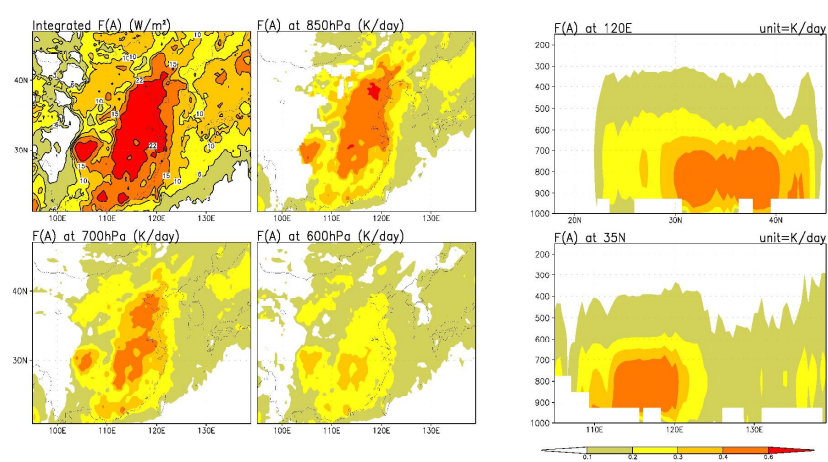

Fig. 11. Anthropogenic aerosol forcing in the atmosphere for May (averaged from 2001 to 2004).

South Asia, large interannual variability occurs downstream. Observations collected downstream should be collected for many years in order to give reliable climatological estimates.

The vertical profile of climatological atmospheric forcing for the dry season (January-March) is contrasted with that for the wet season (June-August) in Fig. 14. For South Asia, the forcing is largest between $1 \mathrm{~km}$ and $2 \mathrm{~km}$ from the surface. Observational studies with the UAV Campaign over the Maldives showed that aerosol solar heating reach peak values slightly above $2 \mathrm{~km}$ (Ramana et al., 2007; Corrigan et al., 2008), roughly consistent with our simulation. The dry season near-surface forcing is a factor of 3 larger than the wet season forcing in our estimate. In case of East Asia, seasonal variation is the opposite. The wet season forcing is larger. Strong seasonality in the South Asian heating seems largely due to seasonal variation in meteorological conditions since surface emission of aerosol precursors maintains similar values throughout a year. In East Asia, the wet season is associated with higher anthropogenic AODs, corresponding comparably to higher heating. This is due to anthropogenic aerosols soaring in summer every year. This period has the weakest flow and the strongest secondary aerosol production, both leading to extended periods between precipitation events with high aerosol loadings. These computational results need further corroboration from observation studies.
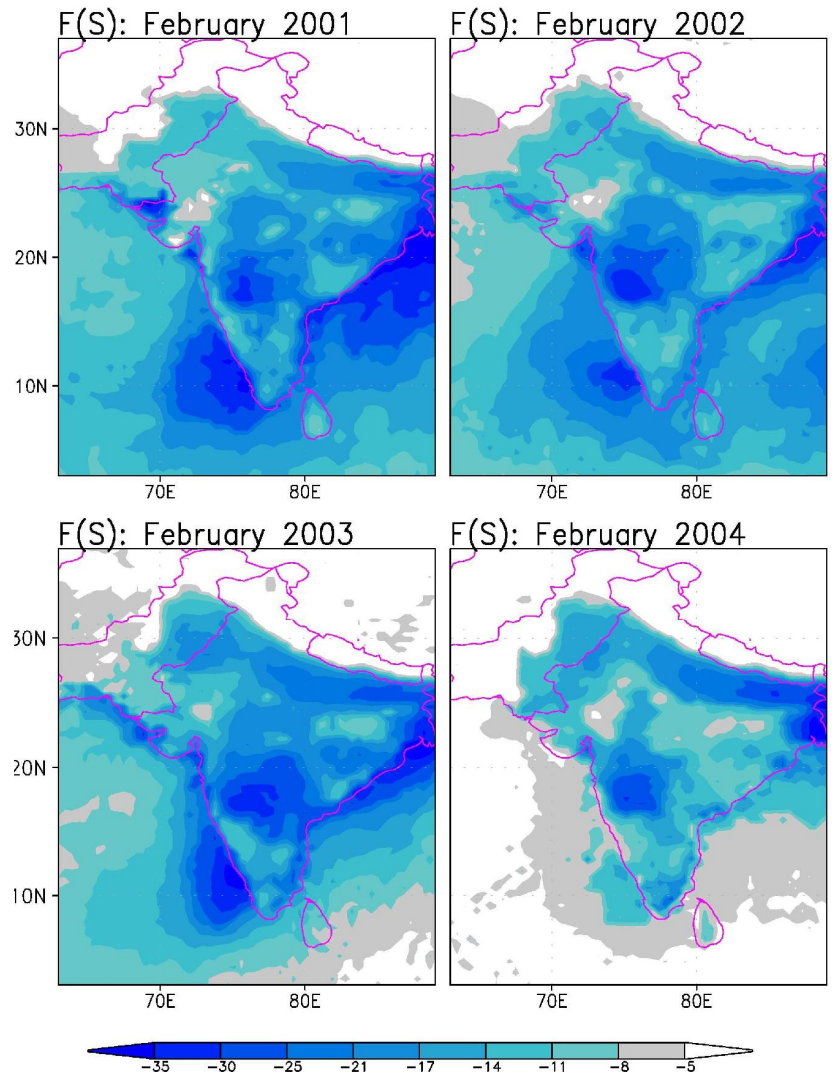

Fig. 12. Anthropogenic aerosol forcing at the surface in units of $\mathrm{Wm}^{-2}$.

In Fig. 15, we compare our $\mathrm{F}(\mathrm{S})$ estimate with Chung et al's (2005) and the CCSM3 simulation for March-May (MAM) period. The CCSM3 (Community Climate System Model Version 3) (Collins et al., 2006) is the state-of-the-art NCAR (National Center for Atmospheric Research) coupled model. The CCSM3 uses aerosol simulation by MATCH (Model for Atmospheric Transport and CHemistry). We ran the CCSM3 with and without $\mathrm{BC}, \mathrm{OC}$ and sulfate aerosols, and took the difference. The CCSM3 was run in a mode in which observed SSTs and standard land surface output replaced the ocean and land surface model components. The 

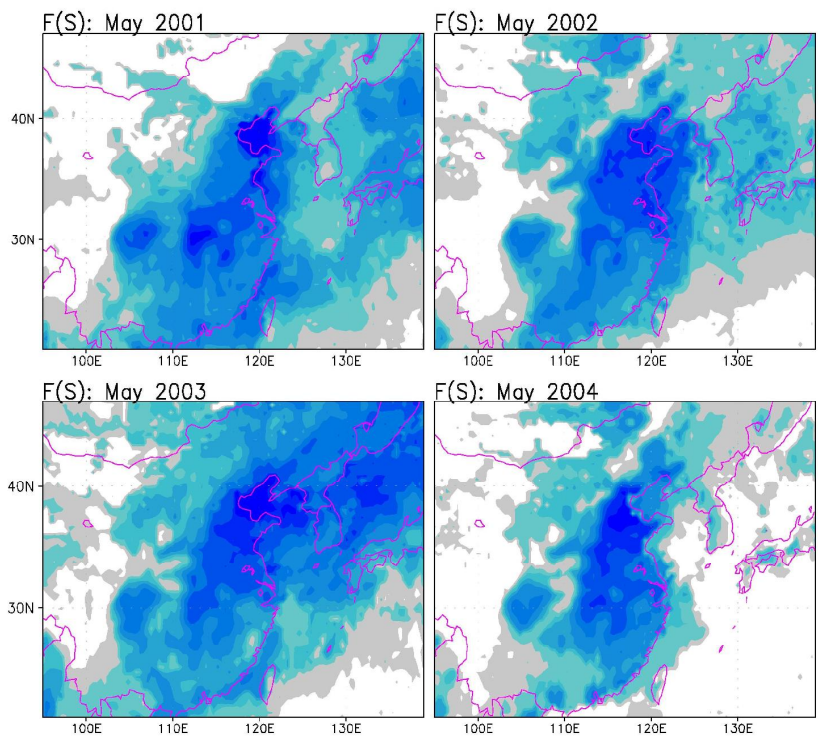

Fig. 13. Anthropogenic aerosol forcing at the surface in units of $\mathrm{Wm}^{-2}$
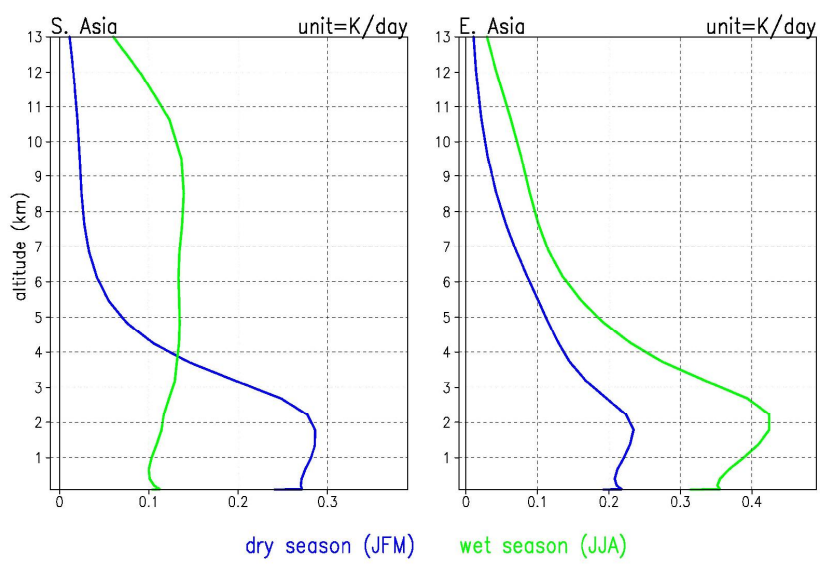

Fig. 14. Vertical profile of climatological anthropogenic aerosol forcing in units of K/day. Plotted are area averages for South Asia $\left(70^{\circ}-90^{\circ} \mathrm{E}\right.$ and $\left.5^{\circ}-25^{\circ} \mathrm{N}\right)$ and East Asia $\left(115^{\circ}-125^{\circ} \mathrm{E}\right.$ and $30^{\circ}-$ $\left.40^{\circ} \mathrm{N}\right)$.

$\mathrm{F}(\mathrm{S})$ estimates in our study and Chung et al. are much greater than the simulation by the CCSM3. Chung et al.'s (2005) estimate is overall similar to the estimate in the present study in magnitude. However, the present study offers much detailed features that can be useful as input for regional climate modeling. The annual mean $\mathrm{F}(\mathrm{S})$ shows similar relationship between the present study, Chung et al. (2005) and the CCM3 simulation. Please note that our anthropogenic computation was obtained by taking the difference between the total-aerosol run and natural-aerosol run, just like in the CCSM3 experiment.

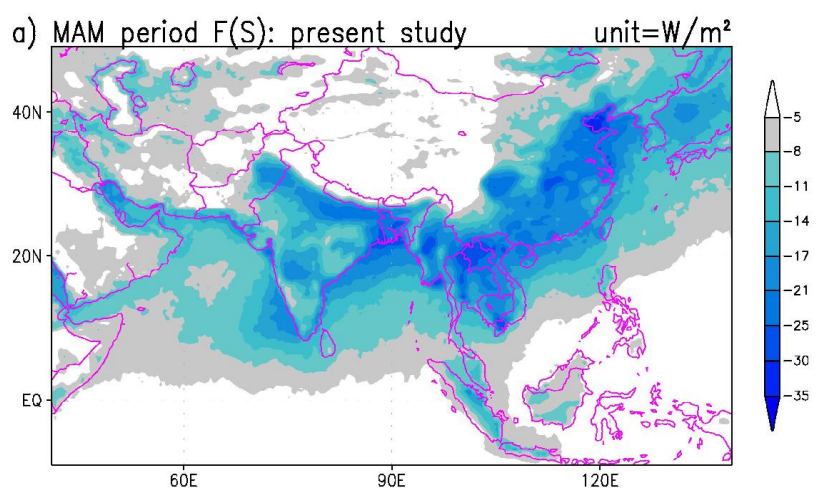

b) MAM period $F(S)$ : Chung et al. (2005)

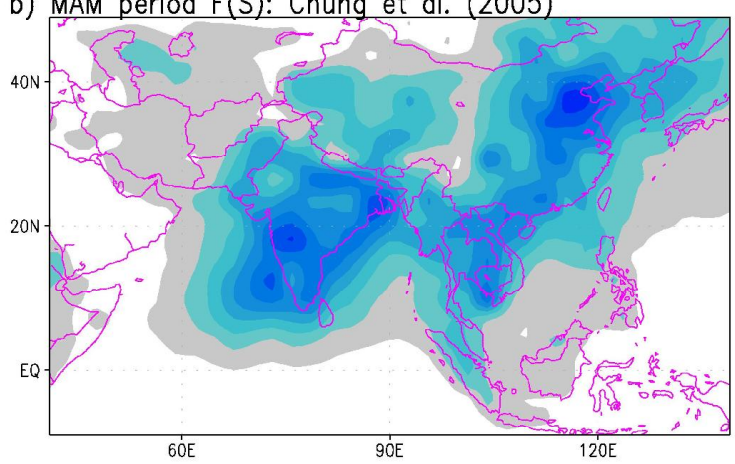

c) MAM period $F(S)$ : CCSM3

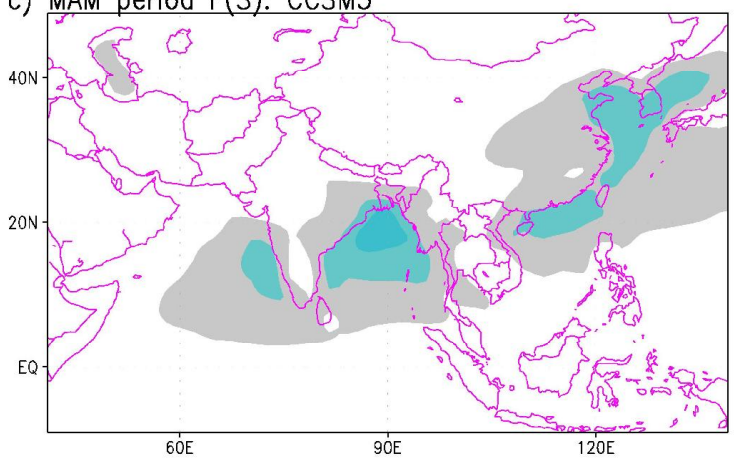

Fig. 15. Comparison of anthropogenic aerosol forcing at the surface: $F(S)$, in units of $\mathrm{Wm}^{-2}$. (a) $\mathrm{F}(\mathrm{S})$ averaged from March to May and from 2001 to 2004 in this study. (b) MAM (March, April, May) period $\mathrm{F}(\mathrm{S})$ from Chung et al. (2005) estimate. (c) MAM period $\mathrm{F}(\mathrm{S})$ from the NCAR CCSM3.0. Shown in all the panels are average-sky aerosol forcing estimates.

\section{Summary and discussion}

Here, we have sought to synthesize a collaborative study between Scripps Institution of Oceanography (SIO), Pacific Northwest National Laboratory (PNNL), and the University of Iowa. In our collaboration, i) the PNNL regional model bounded by the NCEP reanalyses provided meteorology in Asia, ii) SIO integrated MODIS and AERONET data for aerosol observations, iii) the Iowa aerosol/chemistry model STEM-2K1 used the PNNL meteorology to simulate aerosols and the STEM-2K1 aerosol simulation was 
nudged towards aerosol observations, and iv) SIO converted the aerosol simulation into total and anthropogenic aerosol direct solar radiation forcing (DRF) for average cloudy skies. To our knowledge, the present study is one of very few attempts to employ a regional model in an aerosol data assimilation mode. This paper has also described the calculated anthropogenic aerosol radiative forcing (DRF).

The primary finding is that Asia-averaged anthropogenic forcing from the present study is similar to that from Chung et al. (2005) which also used MODIS and AERONET data. When AERONET SSAs were not used, our aerosol assimlation yielded much less $\mathrm{BC}$ concentration which led to much less warming forcing in the atmosphere and much less cooling forcing at the surface. Only with AERONET SSAs, is the present study able to match the computation in Chung et al. (2005). Since the present study employs high-resolution regional modeling, it offers fine-scale structures of aerosol forcing and simulated vertical profile - features not available in Chung et al. (2005). The accuracy of the global anthropogenic direct aerosol forcing estimate in Chung et al. (2005) was recognized by Myhre (2009).

Another progress in this study is the vertical structure of the calculated aerosol concentration and atmospheric aerosol forcing. As Textor et al. (2006) showed, aerosol concentrations in typical aerosol simulation models are concentrated near the surface. Our simulated aerosols also have the largest concentration near the surface but have relatively uniform profiles from the surface to $700 \mathrm{hPa}$, in closer agreement with observation studies (Ramana et al., 2007; Corrigan et al., 2008; Ramanathan et al., 2007) than some of AEROCOM models. The calculated anthropogenic aerosol forcing in the atmosphere is mostly between the surface and $600 \mathrm{hPa}$ with maximum around $800 \mathrm{hPa}$. Our aerosol forcing has maximum above surface, due mainly to low-level cloud that amplifies aerosol forcing above it. Clear-sky forcing calculations support this. Different vertical structures of forcing, though the vertical integrations might be the same, can give very different climate responses. Chung and Zhang (2004) demonstrated that the direct aerosol heating of nearsurface air increases Convective Available Potential Energy (CAPE) whereas the heating above boundary layer decreases CAPE. Furthermore, absorbing aerosols located within low cloud can burn cloud condensate therein (so-called aerosol semi-direct effect; Ackerman et al., 2000), thereby increasing solar radiation reaching the surface. Near-surface concentrated aerosols in typical aerosol simulation models, if implemented into global climate models, would likely paint a misleading picture of the climatic effects of aerosols.

Although the anthropogenic aerosol forcing estimate in the present study is similar, in an Asia-averaged sense, to that of Chung et al. (2005), these two estimates are much greater than the simulated forcing by the CCSM3. How accurate is each estimate? The Indian Ocean Experiment (INDOEX) integrated comprehensive observations and led to aerosol forcing estimates over the South Asian area for
1999 (Ramanathan et al., 2001). We take the INDOEX results as a benchmark for aerosol forcing evaluation. In Table 2, we compare anthropogenic aerosol forcings obtained from the INDOEX, Chung et al. (2005), the present study and the CCSM3. Chung et al. (2005) estimate for 2001-2003 and the present study's for 2001-2004 are somewhat smaller than the 1999 INDOEX results at the surface, and the CCSM3 calculated forcing is even smaller. To gain insight into the differences in forcing estimates, we looked at the present study's aerosol forcing in each year. The surface forcing was $-12.8 \mathrm{~W} / \mathrm{m}^{2}$ in $2001,-14.7$ in $2002,-10.9$ in 2003 and -6.2 in 2004 , giving a range of $-14.7 \sim-6.2 \mathrm{~W} / \mathrm{m}^{2}$. The interannual fluctuation is very large and furthermore the INDOEX result is within our forcing estimates. Thus, it is concluded that the INDOEX results do not nullify the present study's estimate or Chung et al. (2005) but substantially undermine the credibility of the CCSM calculation.

Acknowledgements. The present study was initiated when Chung (first author) was at Scripps Institution of Oceanography, in response to a collaborative NASA project between Scripps Institution of Oceanography (SIO), Pacific Northwest National Laboratory (PNNL), and the University of Iowa. The authors are indebted to Kim and Feng of SIO for their help with literature search. This work was supported by a NASA grant (NNG04GC58G), USA. The Pacific Northwest National Laboratory is operated for the US Department of Energy by Battelle Memorial Institute under Contract DE-AC06-76RLO 1830. Additional funding in finishing the study came from the Academy of Finland Center of Excellence program (project number 1118615), Finland, and Research Agency for Climate Science (RACS 2010-2011), Korea.

Edited by: B. Vogel

\section{References}

Ackerman, A. S., Toon, O. B., Stevens, D. E., Heymsfield, A. J., Ramanathan, V., and Welton, E. J.: Reduction of tropical cloudiness by soot, Science, 288, 1042-1047, 2000.

Abdou, W. A., Diner, D. J., Martonchik, J. V., Bruegge, C. J., Kahn, R. A., Gaitley, B. J., Crean, K. A., Remer, L. A., and Holben, B.: Comparison of coincident MISR and MODIS aerosol optical depths over land and ocean scenes containing AERONET sites, J. Geophys. Res., 110, D10807, doi:10.1029/2004JD004693, 2005.

Adhikary, B., Carmichael, G. R., Tang, Y., Leung, L. R., Qian, Y., Schauer, J. J., Stone, E. A., Ramanthan, V., and Ramana, M. V.: Characterization of the seasonal cycle of South Asian aerosols: A regional-scale modeling analysis, J. Geophys. Res., 112, D22S22, doi:10.1029/2006JD008143, 2007.

Adhikary, B., Kulkarni, S., Dallura, A., Tang, Y., Chai, T., Leung, L. R., Qian, Y., Chung, C. E., Ramanathan, V. and Carmichael, G. R.: A regional scale chemical transport modeling of Asian aerosols with data assimilation of AOD observations using optimal interpolation technique, Atmos. Env., 42(37), 8600-8615, 2008.

Albrecht, B. A.: Aerosols, cloud microphysics and fractional cloudiness, Science, 245, 1227-1230, 1989. 
Carmichael, G. R., Tang, Y., Kurata, G., et al.: Evaluating Regional Emission Estimates Using The Trace-P Observations, J. Geophys. Res., 108(D21), 8810, doi:10.1029/2002JD003116, 2003.

Carmichael, G. R., Adhikary, B., Kulkarni, S., D’Allura, A., Tang, Y., Streets, D., Zhang, Q., Bond, T. C., Ramanathan, V., Jamroensan, A., and Marrapu, P.: Asian Aerosols: Current and Year 2030 distributions and implications to human health and regional climate change, Environ. Sci. Tech., 43, 5811-5817, 2009.

Castro, C. L., Pielke Sr., R. A., and Leoncini, P.: Dynamical downscaling: an assessment of value added using a re-gional climate model, J. Geophys. Res., 110, D05108, doi:10.1029=2004JD004721, 2005.

Charlson, R. J., Langner, J., Rodhe, H., Leovy, C. B., and Warren, S. G.: Perturbation of the Northern Hemisphere radiative balance by black scattering from anthropogenic sulfate aerosols, Tellus, Ser. A., 43, 152-163, 1991.

Chen, F. and Dudhia, J.: Coupling an advanced land surface- hydrology model with the Penn State-NCAR MM5 modeling system. Part I: Model implementation and sensitivity, Mon. Weather Rev., 129, 569-585, 2001.

Chin, M., Ginoux, P., Kinne, S., Torres, O., Holben, B. N., Duncan, B. N., Martin, R. V., Logan, J. A., Higurashi, A., and Nakajima, T.: Tropospheric aerosol optical thickness from the GOCART model and comparisons with satellite and sunphotometer measurements, J. Atmos. Sci., 59, 461-483, 2002.

Chung, C. E., Ramanathan, V., Kim, D., and Podgorny, I. A.: Global anthropogenic aerosol direct forcing derived from satellite and ground-based observations, J. Geophys. Res., 110, D24207, doi:10.1029/2005JD006356, 2005.

Chung, C. E., and Zhang, G. J.: Impact of absorbing aerosol on precipitation: Dynamic aspects in association with CAPE and convective parameterization closure, and dependence on aerosol heating profile. J. Geophys. Res., 109, D22103, doi:10.1029/2004JD004726, 2004.

Coakley, J. A. and Cess, R. D.: Response of the NCAR Community Climate Model to the radiative forcing by the naturally-occurring tropospheric aerosol, J. Atmos. Sci., 42, 1677-1692, 1985.

Collins, W. D., Rasch, P. J., Eaton, B. E., et al.: Simulating aerosols using a chemical transport model with assimilation of satellite aerosol retrievals: Methodology for INDOEX, J. Geophys. Res., 106, 7313-7336, 2001.

Collins, W. D., Bitz, C. M., Blackmon, M. L., et al.: The Community Climate System Model Version 3 (CCSM3), J. Climate, 19, 2122-2143, 2006.

Corrigan, C. E., Roberts, G. C., Ramana, M. V., Kim, D., and Ramanathan, V.: Capturing vertical profiles of aerosols and black carbon over the Indian Ocean using autonomous unmanned aerial vehicles, Atmos. Chem. Phys., 8, 737-747, doi:10.5194/acp-8-737-2008, 2008.

EANET: EANET Data on the Acid Deposition in the East Asian Region: 2004, available online at: http://www.eanet.cc/product. html, 2004.

Eck, T. F., Holben, B. N., Reid, J. S., Dubovik, O., Smirnov, A., O'Neill, N. T., Slutsker, I., and Kinne, S.: Wavelength dependence of the optical depth of biomass burning, urban, and desert dust aerosols, J. Geophys. Res., 104, 31333-31349, 1999.

Giorgi, F., Bi, X. and Qian, Y.: Direct radiative forcing and regional climatic effects of anthropogenic aerosols over East Asia: A regional coupled climate-chemistry/aerosol model study, J. Geo- phys. Res., 107, 4439, doi:10.1029/2001JD001066,2002.

Gong, S. L.: A parameterization of sea-salt aerosol source function for sub- and super-micron particles, Global Biogeochem. Cy., 17, 8/1-8/7, 2003.

Grell, G., Dudhia, J., and Stauffer, D. R.: A description of the fifth generation Penn State/NCAR mesoscale model (MM5). NCAR Tech. Note, NCAR/TN-3981IA, National Center for Atmospheric Research, Boulder, CO, USA, 107 pp., 1995.

Gustafson, W. I. and Leung, L. R.: Regional downscaling for air quality assessment: A reasonable proposition?,, B. Amer. Meteorol. Soc., 88(8), 1215-1227, 2007.

Guttikunda, S. K., Tang, Y., Carmichael, G. R., et al.: Impacts of Asian megacity emissions on regional air quality during spring 2001, J. Geophys. Res., 110, D20301/20301-D20301/20318, 2005.

Hong, S.-Y. and Pan, H.-L.: Nonlocal boundary layer vertical diffusion in a medium-range forecast model, Mon. Weather Rev., 124, 2322-2339, 1996.

Huebert, B. J., Bates, T., Russell, P. B., Shi, G., Kim, Yu, J., Kawamura, K., Carmichael, G. R., and Nakajima, T.: An Overview of ACE-Asia: Strategies for Quantifying the Relationships Between Asian Aerosols and Their Climatic Impacts, J. Geophys. Res., ACE-Asia Special Issue A, 108(D23), 8633, doi:10.1029/2003jd003550, 2003.

Ichoku, C., Remer, L. A., and Eck, T. F.: Quantitative evaluation and intercomparison of morning and afternoon Moderate Resolution Imaging Spectroradiometer (MODIS) aerosol measurements from Terra and Aqua, J Geophys Res., 110, D10S03, doi:10.1029/2004JD004987, 2005.

Johnson, B. T., Christopher, S., Haywood, J.M., Osborne, S.R., McFarlane, S., Hsu, C., Salustrod, C., and Kahn, R.: Measurements of aerosol properties from aircraft, satellite and ground-based remote sensing: A case-study from the Dust and Biomass-burning Experiment (DABEX), Q. J. Roy. Meteorol. Soc., 135, 922-934, 2009.

Kain, J. S. and Fritsch, J. M.: Convective parameterization in mesoscale models: The Kain-Fritsch scheme. The Representation of Cumulus Convection in Numerical Models, Meteor. Monogr., Amer. Meteor. Soc., 46, 165-170, 1993.

Khattatov, B. V., Lamarque, J.-F., Lyjak, L. V., et al.: Assimilation of satellite observations of long-lived chemical species in global chemistry transport models, J. Geophys. Res., 105, 29135-29144, 2000.

Kiehl, J. T., Hack, J. J., and Briegleb, B. P.: The simulated earth radiation budget of the National Center for Atmospheric Research Community Climate Model CCM2 and comparisons with the Earth Radiation Budget Experiment, J. Geophys. Res., 99, 20815-20827, 1994.

Kim, D. and Ramanathan, V.: Solar radiation budget and radiative forcing due to aerosols and clouds, J. Geophys. Res., 113, D02203, doi:10.1029/2007JD008434, 2008.

Kinne, S., Lohmann, U., Feichter, J., et al.: Monthly averages of aerosol properties: A global comparison among models, satellite data, and AERONET ground data, J. Geophys. Res., 108, 4634, doi:10.1029/2001JD001253, 2003.

Kistler, R., Kalnay, E., Collins, W., et al.: The NCEP-NCAR 50year reanalysis: Monthly means CD-ROM and documentation. Bull. Amer. Meteorol. Soc., 82(2), 247-267, 2001.

Koch, D., Schulz, M., Kinne, S., McNaughton, C., Spackman, J. 
R., Balkanski, Y., Bauer, S., Berntsen, T., Bond, T. C., Boucher, O., Chin, M., Clarke, A., De Luca, N., Dentener, F., Diehl, T., Dubovik, O., Easter, R., Fahey, D. W., Feichter, J., Fillmore, D., Freitag, S., Ghan, S., Ginoux, P., Gong, S., Horowitz, L., Iversen, T., Kirkevåg, A., Klimont, Z., Kondo, Y., Krol, M., Liu, X., Miller, R., Montanaro, V., Moteki, N., Myhre, G., Penner, J. E., Perlwitz, J., Pitari, G., Reddy, S., Sahu, L., Sakamoto, H., Schuster, G., Schwarz, J. P., Seland, Ø., Stier, P., Takegawa, N., Takemura, T., Textor, C., van Aardenne, J. A., and Zhao, Y.: Evaluation of black carbon estimations in global aerosol models, Atmos. Chem. Phys., 9, 9001-9026, doi:10.5194/acp-9-9001-2009, 2009.

Leahy, L. V., Anderson, T. L., Eck, T. F., and Bergstrom, R. W.: A synthesis of single scattering albedo of biomass burning aerosol over southern Africa during SAFARI 2000, Geophys. Res. Lett., 34, L12814, doi:10.1029/2007GL029697, 2007.

Leung, L. R., Zhong, S., Qian, Y., and Liu, Y.: Evaluation of regional climate simulations of the 1998 and 1999 East Asian summer monsoon using the GAME/HUBEX observational data, J. Meteorol. Soc. Japan, 82(6), 1695-1713, 2004.

Leung, L. R., Qian, Y. and Bian, X.:: Hydroclimate of the western United States based on observations and regional climate simulation of 1981-2000. Part I: Seasonal statistics, J. Climate, 16, 1892-1911, 2003.

Leung, L. R. and Qian, Y.: Diurnal variations in precipitation and atmospheric heating in Asia based on observations and model simulations, manuscript in preparation, 2008.

Lorenc, A. C.: Analysis methods for numerical weather prediction, Quart. J. Royal Meteor. Soc., 112, 1177-1194, 1986.

Lu, Z., Streets, D. G., Zhang, Q., Wang, S., Carmichael, G. R., Cheng, Y. F., Wei, C., Chin, M., Diehl, T., and Tan, Q.: Sulfur dioxide emissions in China and sulfur trends in East Asia since 2000, Atmos. Chem. Phys. Discuss., 10, 8657-8715, doi:10.5194/acpd-10-8657-2010, 2010.

Myhre, G.: Consistency between satellite-derived and modeled estimates of the direct aerosol effect, Science, 325, doi:10.1126/science, 1174461, 2009.

Olivier, J. G. J. and Berdowski, J. J. M.: Global emissions sources and sinks, A.A. Balkema Publishers/Swets \& Zeitlinger Publishers, The Netherlands, 33-78 pp, 2001.

Penner, J. E., Andreae, M., Annegarn, V. et al.: Climate change 2001: The scientific basis: contribution of working group I to the third assessment report of the Intergovernmental Panel on Climate Change, Cambridge University Press, 289-348, 2001.

Podgorny, I. A., Conant, W. C., Ramanathan, V., and Satheesh, S. K.: Aerosol modulation of atmospheric and solar heating over the tropical Indian Ocean, Tellus, 52B, 947-958, 2000.

Ramana, M. V., Ramanathan, V., Kim, D., et al.: A modeling study of the direct effect of aerosols over the Tropical Indian Ocean, J. Geophys. Res., 106, 24097-24105, 2001.

Ramana, M. V., Ramanathan, V., Kim, D., Roberts, G. C., and Corrigan, C. E.: Albedo, atmospheric solar absorption and heating rate measurements with stacked UAVs, Q. J. Roy. Meteorol. Soc., 133, 1913-1931, 2007.

Ramanathan, V., Crutzen, P. J., Lelieveld, J., et al.: The Indian Ocean Experiment: An integrated analysis of the climate forcing and effects of the Great Indo-Asian Haze, J. Geophys. Res, 106, 28371-28398, 2001.

Ramanathan, V., Ramana, M. V., Roberts, G., et al.: Warming trends in Asia amplified by brown cloud solar absorption, Nature, 448, doi:10.1038/nature06019, 575-578, 2007.

Ramanathan, V. and Carmichael, G.: Global and regional climate changes due to black carbon, Nature Geoscience, 1, 221-227, 2008.

Reisner, J., Rasmussen, R. J., and Bruintjes, R. T.: Explicit forecasting of supercooled liquid water in winter storms using the MM5 mesoscale model, Q. J. Roy. Meteor. Soc., 124B, 1071-1107, 1998.

Rosenfeld, D.: Suppression of rain and snow by urban and industrial air pollution, Science, 287, 1793-1796, 2000.

Rossow, W. B. and Schiffer, R. A.: Advances in understanding clouds from ISCCP, B. Am. Meteor. Soc., 80, 2261-2287, 1999.

Qian, Y. and Leung, L. R.: A long-term regional simulation and observations of the hydroclimate in China, J. Geophys. Res., 112, D14104, doi:10.1029/2006JD008134, 2007.

Satheesh, S. K., Ramanathan, V., Xu, L.-J., Lobert, J. M., Podgorny, I. A., Prospero, J. M., Holben, B. N., and Loeb, N. G.: A model for the natural and antropogenic aerosols over the tropical Indian Ocean derived from Indian Ocean Experiment data, J. Geophys. Res., 104, 27421-27440, 1999.

Schmid, B., Michalsky, J., Halthore, R., Beauharnois, M., Harrison, L., Livingston, J., Russell, P., Holben, B., Eck, T., and Smirnov, A.: Comparison of aerosol optical depth from four solar radiometers during the Fall 1997 ARM intensive observation period, Geophys. Res. Lett., 26, 2725-2728, 1999.

Streets, D. G., Bond, T. C., Carmichael, G. R., et al.: An inventory of gaseous and primary aerosol emissions in Asia in the year 2000, J. Geophys. Res., 108, GTE 30/31-30/23, 2003.

Tang, Y. H., Carmichael, G. R., Kurata, G., et al.: Impacts of dust on regional tropospheric chemistry during the ACE-Asia experiment: a model study with observations, J. Geophys. Res., 109, D19S21, doi:10.1029/2003JD003806, 2004a.

Tang, Y. H., Carmichael, G. R., Seinfeld, J. H., Dabdub, D., Weber, R. J., Huebert, B., Clarke, A. D., Guazzotti, S. A., Sodeman, D. A., Prather, K. A., Uno, I., Woo, J. H., Yienger, J. J., Streets, D. G., Quinn, P. K., Johnson, J. E., Song, C. H., Grassian, V. H., Sandu, A., Talbot, R. W., and Dibb, J. E.: Threedimensional simulations of inorganic aerosol distributions in east Asia during spring 2001, J. Geophys. Res.-Atmos., 109, D19S23, doi:10.1029/2003JD004201, 2004b.

Textor, C., Schulz, M., Guibert, S., Kinne, S., Balkanski, Y., Bauer, S., Berntsen, T., Berglen, T., Boucher, O., Chin, M., Dentener, F., Diehl, T., Easter, R., Feichter, H., Fillmore, D., Ghan, S., Ginoux, P., Gong, S., Grini, A., Hendricks, J., Horowitz, L., Huang, P., Isaksen, I., Iversen, I., Kloster, S., Koch, D., Kirkevåg, A., Kristjansson, J. E., Krol, M., Lauer, A., Lamarque, J. F., Liu, X., Montanaro, V., Myhre, G., Penner, J., Pitari, G., Reddy, S., Seland, Ø., Stier, P., Takemura, T., and Tie, X.: Analysis and quantification of the diversities of aerosol life cycles within AeroCom, Atmos. Chem. Phys., 6, 1777-1813, doi:10.5194/acp-61777-2006, 2006.

Twomey, S.: Atmospheric aerosols, Elsevier Sci., New York, USA, 302 pp., 1997.

van der Werf, G. R., Randerson, J. T., Giglio, L., Collatz, G. J., Kasibhatla, P. S., and Arellano Jr., A. F.: Interannual variability in global biomass burning emissions from 1997 to 2004, Atmos. Chem. Phys., 6, 3423-3441, doi:10.5194/acp-6-3423-2006, 2006. 
von Storch, H., Langenberg, H., and Feser, F.: A spectral nudging technique for dynamical downscaling purposes, Mon. Weather Rev., 128, 3664-73, 2000.

Wesely, M. L. and Hicks, B. B.: A review of the current status of knowledge on dry deposition, Atmos. Environ., 34, 2261-2282, 2000.

Xie, P. and Arkin, P. A.: Analyses of Global Monthly Precipitation Using Gauge Observations, Satellite Estimates, and Numerical Model Predictions, J. Climate, 9, 840-858, 1996.

Yu, H., Kaufman, Y. J., Chin, M., Feingold, G., Remer, L. A., Anderson, T. L., Balkanski, Y., Bellouin, N., Boucher, O., Christopher, S., DeCola, P., Kahn, R., Koch, D., Loeb, N., Reddy, M. S., Schulz, M., Takemura, T., and Zhou, M.: A review of measurement-based assessments of the aerosol direct radiative effect and forcing, Atmos. Chem. Phys., 6, 613-666, doi:10.5194/acp-6-613-2006, 2006.
Zhang, Q., Streets, D. G., Carmichael, G. R., He, K. B., Huo, H., Kannari, A., Klimont, Z., Park, I. S., Reddy, S., Fu, J. S., Chen, D., Duan, L., Lei, Y., Wang, L. T., and Yao, Z. L.: Asian emissions in 2006 for the NASA INTEX-B mission, Atmos. Chem. Phys., 9, 5131-5153, doi:10.5194/acp-9-5131-2009, 2009. 